\title{
Spirit, mind and body: the archaeology of monastic healing
}

\author{
Book or Report Section
}

Published Version

Creative Commons: Attribution-Noncommercial-No Derivative Works 4.0

Open access

Gilchrist, R. (2020) Spirit, mind and body: the archaeology of monastic healing. In: Gilchrist, R. Sacred Heritage: Monastic Archaeology, Identities, Beliefs. Cambridge University Press, Cambridge, pp. 71-109. ISBN 9781108678087 doi: https://doi.org/10.1017/9781108678087.004 Available at https://centaur.reading.ac.uk/88522/

It is advisable to refer to the publisher's version if you intend to cite from the work. See Guidance on citing.

To link to this article DOI: http://dx.doi.org/10.1017/9781108678087.004

Publisher: Cambridge University Press

Publisher statement: An online version of this work is published at doi.org/10.1017/9781108678087 under a Creative Commons Open Access license CC-BY-NC-ND 4.0 which permits re-use, distribution and reproduction in any medium for non-commercial purposes providing appropriate credit to the original work is given. You may not distribute derivative works without permission. To view a copy of this license, visit https://creativecommons.org/licenses/by-nc$\mathrm{nd} / 4.0$. All versions of this work may contain content reproduced under license from third parties. Permission to reproduce this third-party content must be obtained from these third-parties directly.

All outputs in CentAUR are protected by Intellectual Property Rights law, including copyright law. Copyright and IPR is retained by the creators or other copyright holders. Terms and conditions for use of this material are defined in 
the End User Agreement.

www.reading.ac.uk/centaur

\section{CentAUR}

Central Archive at the University of Reading

Reading's research outputs online 


\section{THREE}

\section{SPIRIT, MIND AND BODY: THE ARCHAEOLOGY OF MONASTIC HEALING}

\section{INTRODUCTION: THE MONASTIC HEALING REGIMEN}

This chapter examines a specific aspect of the monastic lifestyle - how monastic identity and Christian ideas about the body influenced the prevention and treatment of illness. Spiritual and physical health were regarded by medieval people as indivisible: the very existence of disease was attributed to Original Sin and personal experience of illness was frequently understood as punishment for a bad life. Pain was believed to cleanse the soul of sin and to prepare the sinner for judgement after death (Rawcliffe 2002). To be truly healed required spiritual repentance: the medieval monastic regimen fully integrated treatment of the Christian body and soul, connecting the sensory and emotional with the material world. The prevailing view of medical historians is that treatment in the medieval infirmary was based primarily around spiritual succour and basic nursing care. What does archaeological evidence reveal about the nature of care in medieval monastic infirmaries and hospitals, and the differences between them? Can archaeology detect more active, therapeutic technologies in monastic healing? Can we discern regional or chronological patterns that may relate to earlier (indigenous) healing traditions and therapeutic landscapes?

The archaeology of monastic healing focuses on the full spectrum of healing technologies, from managing the body in order to prevent illness, through to the treatment of the sick and preparation of the corpse for burial. Monastic 
healing is examined here through a practice-based approach which emphasises agency and embodiment: archaeology and material culture are used to consider how monastic experience responded to illness, ageing and disability. This framework is influenced by the material study of religion, which interrogates how bodies and things engage to construct the sensory experience of religion (Meyer et al. 20I0; Mohan and Warnier 20I7; Morgan 20I0), and by practicebased approaches in archaeology, which examine the active role of space and material culture in shaping religious agency and embodiment (Fogelin 2007; Petts 20II; Swenson 20I5; Thomas et al. 2017).

Monasteries of the reformed orders lived communally, sharing daily liturgical routines in an enclosed space that was largely shut off from the world. The sixth-century Rule of St Benedict provided the blueprint for monastic identity and materiality: it disciplined the body through celibacy, fasting, and daily and seasonal routines for physical movement, prayer, work, study, talking, eating and sleeping. These 'disciplinary practices' (Asad 1987) or 'techniques of the body' (Mauss 2006 [I936]; Galliot 20I5) constructed the monastic sense of self and created a programme for communal living. The monastic body was shaped by the interaction of bodily techniques and material culture, including monastic constructs of space, diet, health, hygiene and therapeutic treatments. A special place was reserved in each monastic community for the sick and elderly: 'before all things and above all things care must be taken of the sick, so that they may be served in the very deed as Christ Himself; for He said: "I was sick and ye visited me ..."” (McCann I952: 9I). The strict monastic lifestyle was mediated by the need to care for the sick, with flexibility required especially around monastic rules that governed diet and communal eating and sleeping.

The Benedictine Rule emphasised the central role of hospitality and charity in monastic life, leading to the foundation of almonries located at the gates of monasteries. Independent hospitals were also established for the care of the poor and sick in medieval society, founded by prominent ecclesiastics, aristocrats, members of the royal family and, in the later Middle Ages, merchants, guilds and urban communities. These were not hospitals in the modern sense, providing medical intervention and emergency care - they provided 'warmth, rest, basic nursing care and nourishing food' (Rawcliffe 20II: 74). The larger and wealthier medieval hospitals were quasi-monastic institutions that followed the Augustinian Rule. They embodied Christian teachings on charity and offered welfare to the worthy and repentant poor. Care in the infirmary was based around the concept of the liturgy and a healing regime supported by the sacraments, holy relics, devotional imagery and sacred music. Both monastic and hospital infirmaries were provided with a chapel or high altar at which daily masses were performed; patient beds were placed so that they could witness the transubstantiation, the moment at which the Eucharistic wafer 


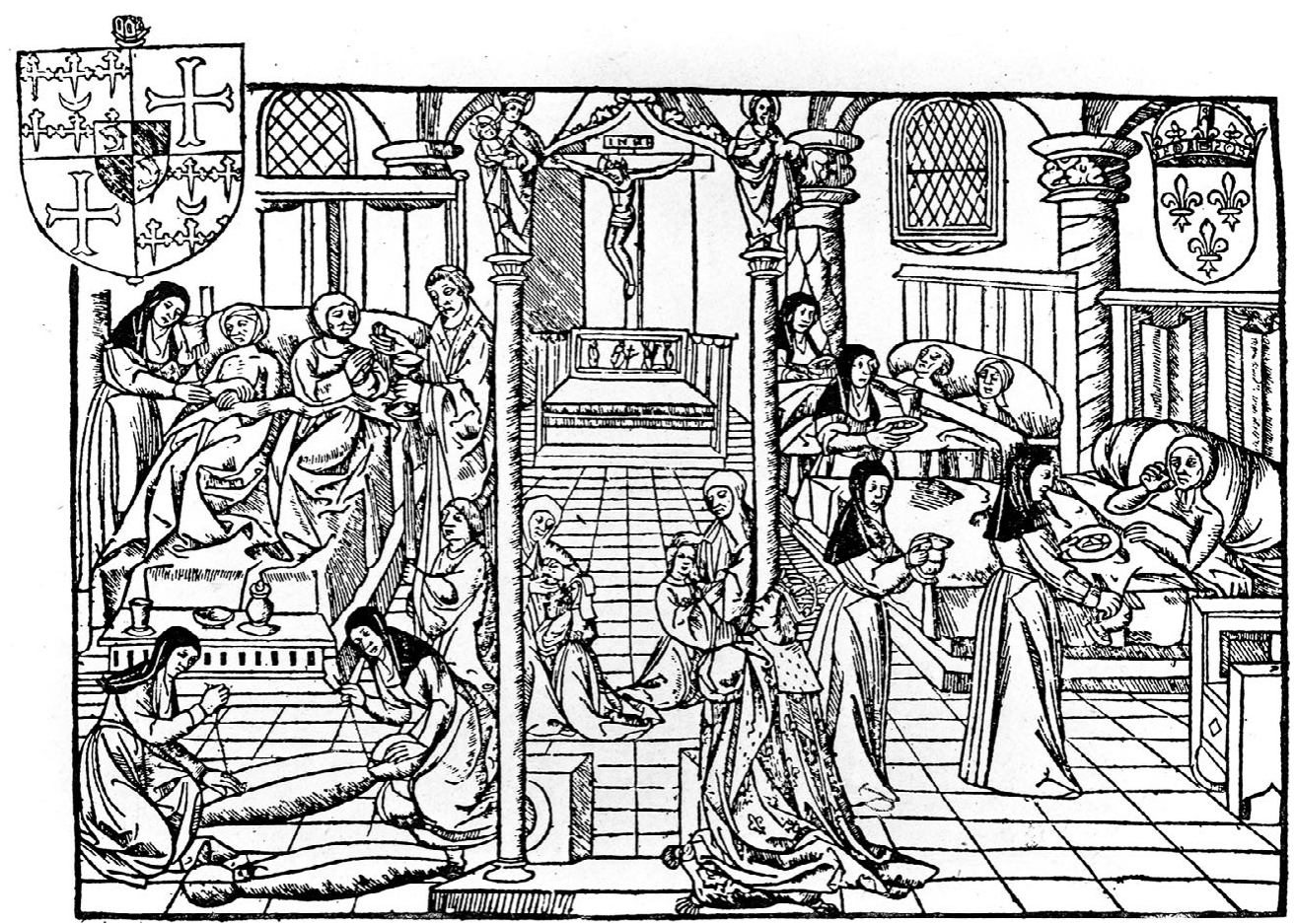

3. I A hospital ward in the Hotel Dieu, Paris, facsimile after a I6th-century original. Wellcome Collection, Public Domain

transformed miraculously into the body of Christ (Figure 3.I). This ritual was regarded as the most efficacious medicine for medieval Christians, impacting on all of the senses, like 'a powerful electric current coursing through the body' (Rawcliffe 20I7: 78). Hospitals might be seen in one respect as a form of 'spiritual policing', reinforcing Christian compliance and enforcing a regimen of confession and prayer that promised health and salvation (Rawcliffe I999: 7). However, these emotional and psychological elements are likely to have made a positive contribution to supporting therapeutic treatment (Horden 2007). Medieval monastic and hospital infirmaries demonstrate the integral relationship between ritual and healing technologies, and how Christian techniques of the body combined sensory, emotional and material experience to construct a religious imaginary.

Medieval monasteries had access to Ancient Greek medical texts, newly translated from the twelfth century onwards from Arabic, Greek and Hebrew into Latin. Pharmacological and surgical treatises from the Islamic world also figured prominently in their libraries. Monasteries built up impressive collections of medical treatises and herbals, guides to plants and their uses, which often included practical instructions for the preparation of therapeutic remedies (Green 2009). The instructions given in herbals relied on a strong element of tacit knowledge, indicating that substantial practical training underpinned 
the practice of herbal medicine (Van Arsdall 20I4: 49). Medicine became more abstract and academic in the twelfth century, a more theoretical approach that broke with the earlier, empirical tradition (Rawcliffe 20II: 400). Influenced by the Greek physician Galen (c.129-200 CE), medieval medical theory was based on the four humours of the body interacting with the four 'natural' elements and the six 'non-naturals'. The human body was believed to be made up of four natural elements, which also made up the universe: fire, water, earth and air. Health and temperament were determined by the balance between the four humours, which corresponded with the bodily substances of phlegm, blood, yellow bile and black bile. Fire, which was hot and dry, produced yellow bile in the body, and led to a choleric complexion. Water, which was cold and wet, produced phlegm, and the phlegmatic complexion. Earth, thought of as cold and dry, was black bile in the body, and associated with the melancholic complexion. Air, regarded as hot and wet, made blood, and the sanguine complexion (Rawcliffe I995). The 'non-naturals' were additional factors believed to influence health: ambient air, food and drink, exercise and rest, sleeping and waking, evacuation and repletion, and the emotions (referred to as the passions or 'accidents' of the soul) (Horden 2007: I34).

Monastic techniques of the body were an ideal fit with the medical concept of the Regimen Sanitatis, the proper management of the body to achieve an equilibrium through diet and moderation (Rawcliffe 2002: 58). This was based on the Greek model of the regimen of health, the idea that disease can be prevented through careful regulation of diet, hygiene and care for the body. The goal was to achieve harmony between body and soul through moderation of behaviour, with the regimen varied to suit individual 'complexions' that differed according to age, sex and the balance of the humours (Sotres I998: 29I-2). In practice, it involved eating a balanced diet, eliminating excess bodily fluids, living in a clean environment, taking regular exercise and rest, and avoiding stress (Bonfield 20I7: IO2). For medieval monastics, the regimen involved an emphasis on spiritual, mental and physical discipline, as well as attention to sanitation, fresh water, personal hygiene and the balancing of the humours through diet and phlebotomy (blood-letting). Exercise and recreation in green spaces were also considered to be important, for example walking in the monastic orchards, vineyards and gardens, where scented plants helped to rebalance the humours (Rawcliffe 2008). The Benedictine Rule encouraged gardens for contemplation and recreation, provided that they were enclosed and secluded (Skinner and Tyers 20I8: 7). On average, each monk was bled every six to seven weeks, followed by three days' recuperation in the infirmary, where the rules governing diet and liturgical routines were relaxed. The division between academic and empirical approaches in medieval medicine was strengthened by the Fourth Lateran Council of I2I5, which prohibited all clergy in higher orders from performing medical procedures 
involving bloodshed, in case they resulted in accidental murder or the pollution of the Eucharist when mass was celebrated. From this date onwards, monasteries employed laymen such as barber-surgeons to perform surgery and phlebotomy (Rawcliffe 2002: 46).

\section{THERAPEUTIC LANDSCAPES}

The medical historian Carole Rawcliffe has commented on the absence of documentary evidence for the foundation of specialist institutions for the care of the sick before the Norman Conquest. From I070 to I200, around 250 hospitals were founded in England (Rawcliffe 20II: 74). Of twenty hospitals known in Wales, only the site of Llawhaden (Pembrokeshire) has been excavated (Huggon 20I8: 847). Derek Hall has found evidence for I 78 hospitals in medieval Scotland, based on documents and place name evidence such as 'Spittal' and 'Maison Dieu' (Hall 2006: 44). The height of hospital foundation in Scotland appears to have been in the fifteenth century, in contrast with the twelfth-century boom in England. Some of these hospitals were specialist institutions for the care of 'lepers': skeletal evidence confirms isolated cases of leprosy in medieval Scotland, ranging geographically from Whithorn in the southwest to Orkney in the northeast. Leprosaria were founded in major burghs and in the countryside but there are no documented leper hospitals in the southwest, Highlands or Northern Isles (Oram 2011: 204-7). The relatively low level of institutional charity in Scotland before the fifteenth century may be explained partly by the Scottish social context. Clan chiefs were responsible for providing shelter for the needy and vulnerable and they sometimes maintained their own healers; parish clergy in the West Highlands were also expected to support the poor and to provide hospitality for travellers and pilgrims (Hamilton I98I: 35; MacDonald 20I4: 2I-2). It is also possible that Scottish hospitals recorded in the fifteenth century had been in existence for some time - the historical dates of hospital foundations are based on the earliest surviving documentary references. We know that the model of Christian charity was actively promoted in Scotland from around IIoo: Turgot's life of Margaret presented the Scottish queen as an exemplar who served Christ by feeding the poor and supporting monastic communities (Hammond 20I0: 68).

Historical models for the chronology of hospital foundation may be challenged by recent archaeological work at the sites of medieval hospitals in England. Excavations at three sites have identified specialist cemeteries predating the Norman Conquest, suggesting that some medieval hospitals may have 'prehistories' as Anglo-Saxon healing centres. Excavations at the leper hospital of St Mary Magdalene, Winchester, have yielded structural evidence and radiocarbon dates confirming an early phase of cemetery and buildings at the site, prior to its formal foundation as a leper hospital in the mid-twelfth 

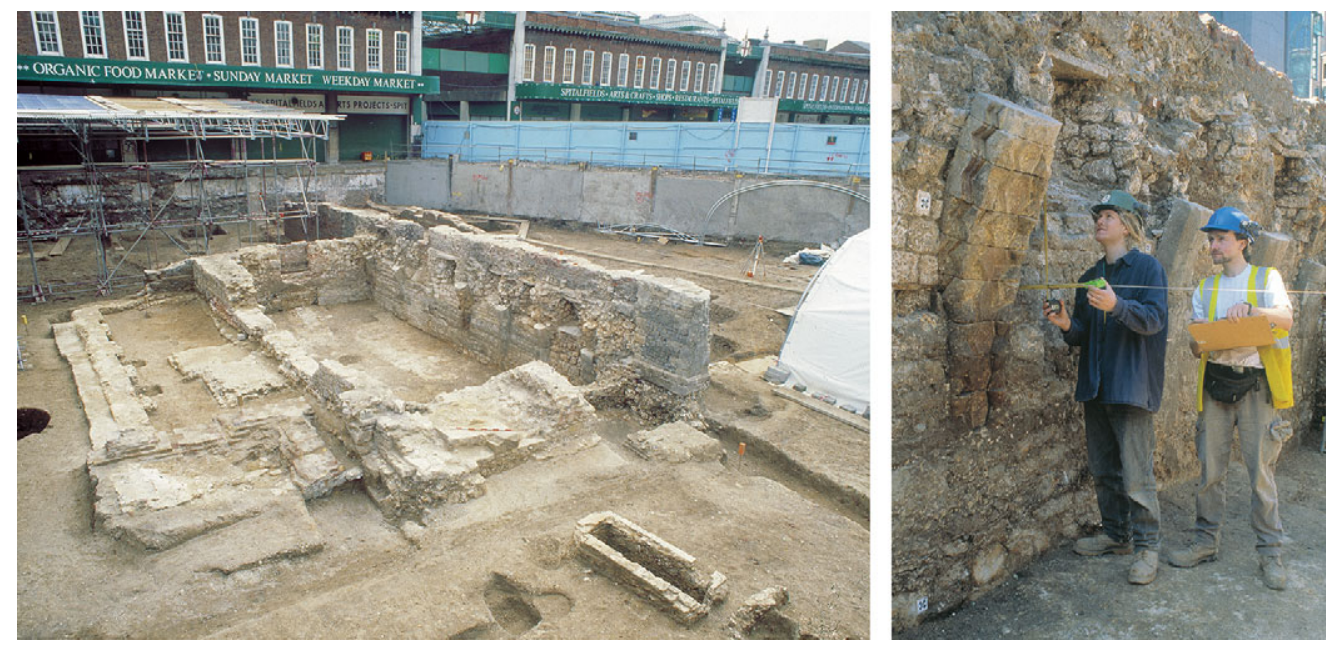

3.2 Remains of the charnel chapel at St Mary Spital, London. (C) Museum of London Archaeology

century (Roffey 20I2). Radiocarbon dating of two leprous skeletons from Winchester may place them before the Norman Conquest, disputing the conventional view that leprosy was not widespread before the twelfth century, and that the first leper hospital in England was Archbishop Lanfranc's foundation at Harbledown in Kent (c.1084). Radiocarbon dates from the hospital of St Mary Magdalene, Partney (Lincolnshire), suggest that some kind of charitable institution was in place before the medieval hospital was founded c.IIIs on the site of a middle Saxon monastery (Atkins and Popescu 20Io). Excavations at the site of St Mary Spital, London, also hint of earlier origins: the hospital was founded in II97 on an existing cemetery that is undocumented historically and pre-dates the hospital foundation by approximately ioo years. Phasing is based on extensive radiocarbon dating and Bayesian statistical modelling. Before the documented foundation of the hospital, the site was used for mass burial in large pits, suggesting an emergency burial ground. An early fourteenth-century charnel chapel at St Mary Spital reused twelfthcentury mouldings, perhaps indicating the symbolic incorporation of fabric to commemorate an earlier church on the site (Connell et al. 20I2: 3-5) (Figure 3.2).

Taken together, these cases begin to question the traditional view that hospitals were a Norman revolution in health care. What types of charitable institution may have preceded the Norman hospital? What determined the selection of location for the foundation of medieval hospitals - could the choice have been influenced by earlier use of the locality? Medieval churches and monasteries often reused early medieval or Roman sites for symbolic reasons, even if there was no direct continuity of use (Morris 1989). Were medieval hospitals established at locales already esteemed as 'therapeutic 
landscapes', places with an enduring reputation for providing physical, spiritual and mental healing (Gesler 2003)? In Scotland, some hospitals may have been associated with earlier healing wells. For example, Trinity Hospital, Edinburgh, is believed to have been founded by King Malcolm IV (II53-65) at the site of a healing spring, and the leprosarium at Kingcase, St Ninian's Hospital near Prestwick (South Ayrshire), was said to have been founded by Robert the Bruce after he benefited from drinking the healing waters from the well (Walsham 20II: 5I).

There were healing wells and springs located all over Scotland, as many as 600 in the later Middle Ages, and some of those in the Highlands remained associated with healing rites up to the modern period (MacKinlay I893; Todd 2000: I40). St Fillan's Well (Stirling) in the southeast Highlands, and Loch Maree (Wester Ross) in the northwest, were both connected with folk cures for insanity, involving immersion and ritual practices (see Chapter I; Figures I.6 and I.7). Both places are associated with Celtic saints and retain evidence for early medieval archaeology, suggesting a longstanding reputation as therapeutic landscapes. Near St Fillan's Well is the ruined church of St Fillan, and on Eilean Maree, the well is associated with a chapel and cemetery connected with St Maelrubha (Donoho 20I4). Medieval wells may have developed on the sites of pre-Christian water cults: Adomnán's Life of Columba, written at the very end of the seventh century, describes how the saint converted wells that previously had been the focus of pagan worship. When visiting Pictland, Columba heard of a well that caused people to be struck down by leprosy or blindness after they came into contact with the water. He blessed the well in the name of Christ, before washing his hands and feet and then drinking water from the well. The vita records that 'after the saint had blessed it and washed in it, many ailments among the local people were cured by that well' (Life of St Columba Book II: II; Sharpe I995: I62-3).

The Isle of May (Fife) is a strong candidate for an early therapeutic landscape that continued in use over a thousand years. The Benedictine monastic cell at May represents a relatively short episode in the history of the island, founded in the twelfth century and abandoned in the thirteenth century. Skeletons excavated from the cemetery date from the fifth to the late sixteenth century, confirming that the island was a pilgrimage centre for a much longer period (see Figure 2.I4). There is no firm historical evidence for a healing shrine at May but there is an early sixteenth-century record in the Aberdeen Breviary of a healing well, which drew female pilgrims to May who hoped to conceive a child (Willows 20I5). Fifty-eight articulated skeletons were excavated at May, representing around 20 per cent of the total cemetery area. Over 80 per cent of these burials dated to the earlier phase of use, spanning the fifth to the midtwelfth century, and pre-dating the foundation of the monastic cell. Analysis by Marlo Willows has shown that the skeletal population was striking in three 
respects: first, the skeletons were predominantly male (94 per cent of sexed burials); secondly, almost all of them showed at least one pathological lesion (97 per cent); and thirdly, there was a high proportion of young adults, aged under 25 years ( 22 per cent). The predominance of males suggests either a male religious community or that sexual segregation was observed in the location of burial. Only a fifth of the cemetery was excavated and it is possible that there was a designated area for female burial that was not located (James and Yeoman 2008: I6). The high incidence of disease among young adults may suggest something distinctive at May - perhaps a cult site that attracted infirm young men, both lay and religious male pilgrims in search of a cure (Willows 20I5). We know that medieval cults sometimes appealed to particular social constituencies: for instance, the miracle stories of St Æbbe of Coldingham indicate that she attracted especially female, poor and younger pilgrims (Bartlett 2003: xxv).

\section{THE ARCHAEOLOGY OF MEDIEVAL HEALING}

Archaeology has enormous potential to contribute to the history of medicine but care is needed in how we define the framework for analysis. Archaeological insight to the more academic, theoretical constructs of medieval medicine is likely to be limited, but material sources provide new perspectives on the broader empirical tradition delivered by a diverse range of practitioners physicians (often monks and priests), surgeons, bone-setters, apothecaries, herbalists, lay-sisters and midwives. As noted above, the archaeology of medieval healing focuses on the full spectrum of healing technologies, from managing the body in order to prevent illness, through to the treatment of the sick and the preparation of the corpse for burial. Monastic hospitals and infirmaries are the most direct form of archaeological evidence for medieval healing, providing the spatial context in which the sick were nursed. Material culture from these institutional contexts can sometimes be identified as having a specialist medical function. However, many objects such as knives and tweezers were multi-purpose and would not necessarily be considered to be medical objects if they were recovered from other spatial contexts. A small number of specialist therapeutic items have been excavated from graves in monastic and hospital cemeteries: the wider treatment of the corpse can also be seen in the context of the transformation of the Christian body in preparation for judgement and resurrection (see Chapter 4).

Skeletal evidence from excavated monastic and hospital cemeteries provides insight to disease, disability and care for the sick. My particular focus here is on possible evidence for medical intervention practised at medieval institutions, although this is difficult to discern. For example, at the Augustinian priory of St Mary Merton (Surrey), I3 per cent of the skeletal population of 

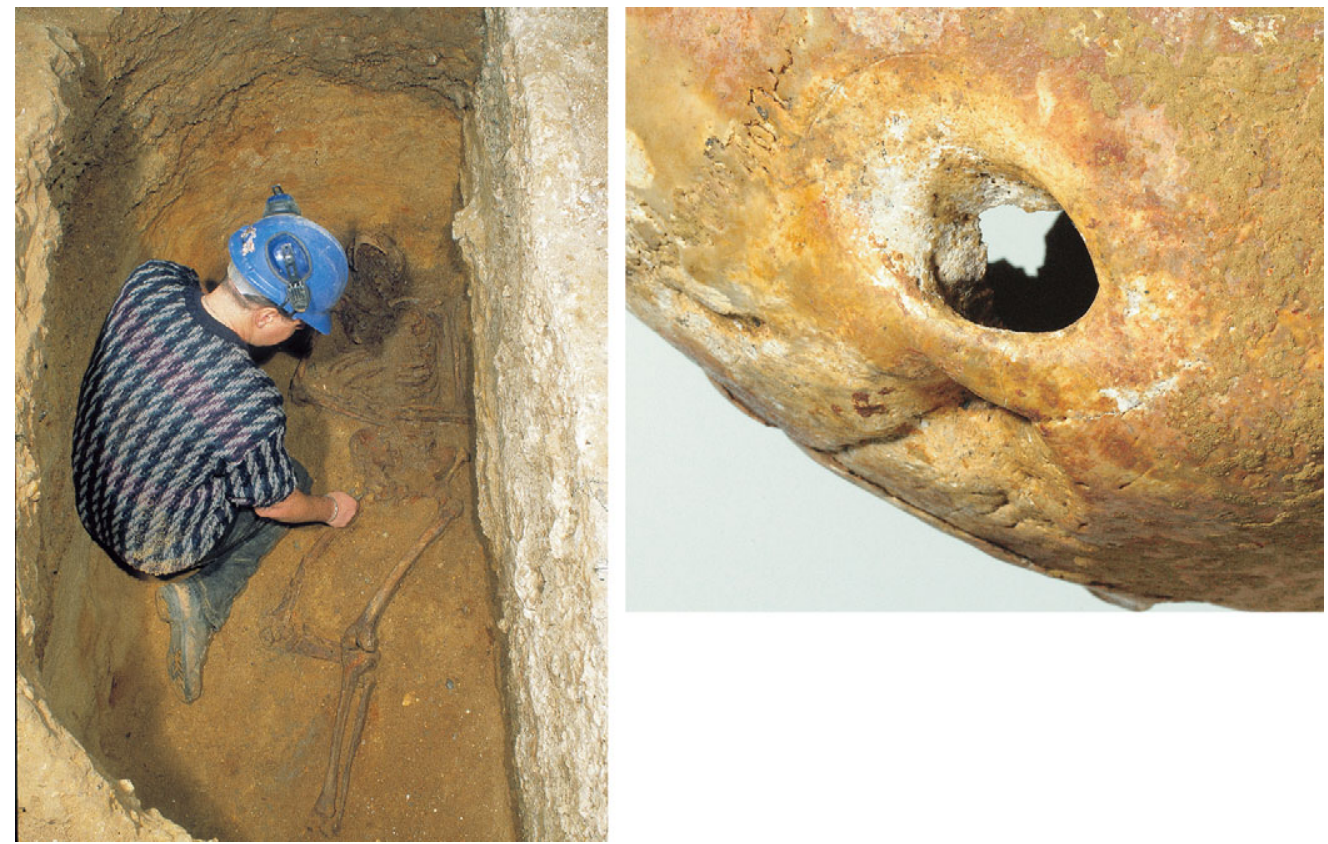

3.3 Skeletons from St Mary Spital, London, showing evidence for amputation and trephination. (C) Museum of London Archaeology

664 individuals showed evidence of healed fractures, most of which were wellaligned (Miller and Saxby 2007: I26). This suggests some degree of medical care, perhaps from bone-setters or barber-surgeons, and not necessarily by monastic infirmarers. In Scotland, well-healed fractures were recorded in skeletons excavated from the Carmelite friaries of Aberdeen, Perth and Linlithgow, and Cistercian Newbattle Abbey (Gooder et al. 2004; MacLennan 200I). Investigations at the Augustinian hospital priory of St Mary Spital in London represent the largest cemetery excavation undertaken in Europe, with I0,500 skeletons analysed (Connell et al. 20I2; Harward et al. 20I9; Thomas et al. I997). There were 550 cases of fractured long bones, half of which showed some deformity in healing, and 8.5 per cent failed to heal. In rare cases, it is possible to detect the impact on the skeleton of other forms of therapeutic intervention: a high status, late medieval female from Ripon Minster (now Cathedral, North Yorkshire) showed abnormal changes to the bones of the thoracic cavity. The skeletal changes are interpreted as the result of compression bandaging to treat 'pigeon chest' (Groves et al. 2003).

There were five cases of surgical intervention at St Mary Spital: two amputations and three trephinations, in which a piece of the cranium is cut and removed (Connell et al. 20I2: 202, 2I2) (Figure 3.3). It is likely in all of these cases that the surgery was intended to treat a head wound, for example to remove splinters of bone or release pressure following a head injury. Surgical 
intervention of this type was extremely rare, with only five certain cases of trephination and two of amputation recorded from other medieval sites in Britain, including hospitals in Chichester, Newark and Dublin (Roberts and Cox 2003: 25I-2). The later medieval phase of Whithorn Cathedral Priory (Dumfries and Galloway) produced three further possible cases of trephination (Hill I997: 529-30). Such operations were performed by surgeons who were members of the laity, rather than by monks or priests; both the surgeon and the patient received the sacrament of confession before the operation, revealing the overlap between religious and medical rituals (Rawcliffe I999: 318). Further cases of amputation have been identified in skeletons excavated from leprosaria, indicating surgical intervention in advanced cases of leprosy. At St Mary Magdalen, Winchester (Roffey and Tucker 20I2: I75), and St James and St Mary Magdalene, Chichester (Magilton et al. 2008: 258-9), there were single cases of lower leg amputations.

A small number of skeletons from monastic cemeteries indicate significant disability, suggesting that long-term care was provided for individuals with degenerative conditions. At Merton Priory this included cases of spina bifida occulta and conditions affecting the knee and foot that would have affected mobility (Miller and Saxby 2007: 276). At St Mary Spital there was significant evidence for impairments to major joints and long bones, including tuberculosis, as well as spinal anomalies. The majority of cases resulted from dislocations of the shoulder and hip. All age groups were affected, including children, and females were less likely to recover, perhaps suggesting that women received inferior care or were less able to take time out from daily work routines in order to heal (Connell et al. 20I2: I90-2). At Newbattle Abbey (Midlothian), long-term care may have been required for an individual with an unreduced dislocated shoulder and another with a vertebral fracture that became infected (Gooder et al. 2004: 392). These cases confirm that individuals with impeded mobility were supported by their communities, but it is not clear whether they received institutional care or were instead nursed in the home environment. Because monasteries and hospitals accepted the wider lay population for burial in the cemetery, we do not know whether these individuals were cared for in the infirmary or in domestic contexts.

A systematic approach has been developed to consider individual cases of disability in detail: the 'bioarchaeology of care' is a framework for assessing the evidence and possible health-related care of individuals with pathologies that indicate long-term disease and disability (Tilley 20I7). It advocates four stages: (I) diagnosing the pathology and its clinical implications; (2) assessing disability and its functional implications for everyday activities; (3) assessing the level of support and care required and the duration of care-giving; and (4) interpreting social context, identity and relationships, including the agency of both caregivers and recipients. Charlotte Roberts has applied the 'index of care' to an 
individual skeleton excavated from the leper hospital of St James and Mary Magdalene, Chichester (Roberts 2017). The male (aged 25-35) suffered from dental disease, respiratory disease, spinal degeneration and an infection, likely leprosy, which caused facial and postcranial bone changes consistent with lepromatous leprosy (Roberts 2017: II4). Roberts paints a vivid picture of the man's likely experience of disability; for example, dental disease would have made it painful for him to eat, while nasal congestion from leprosy would have resulted in loss of his sense of taste and smell, likely causing diminished appetite and weight loss. Nerve damage to his hands and feet would have made it difficult for him to walk and to complete basic tasks. The man would have needed shelter, sustenance and assistance with everyday tasks and mobility; his condition would have required constant encouragement to eat and drink, care for ulcers and skin lesions and protection to his hands and feet to guard against further damage. The 'index of care' model provides deeper insight to this man's lived experience of leprosy but the evidence does not allow his social context to be fully ascertained. As Roberts notes, we cannot assume that the man was a patient in the leper hospital - he may have been cared for elsewhere, before interment in the hospital cemetery. Social attitudes towards his disease, and his relationship to his care-givers, cannot be inferred directly from the archaeological context of his burial (Roberts 20I7: II8). As further medieval case studies are documented using the index of care, it may be possible to make relative assessments of the care given to individuals with specific diseases in medieval hospitals, monasteries and domestic environments. However, it is not yet clear whether the framework will enable such comparative assessments or whether it is limited to more generic assessments of the lived experience of particular disabilities.

Diet was an important component of the monastic regimen, linked to both preventative medicine and therapeutic treatments: hot and cold humours were believed to be generated by the quality of food and drink (Bonfield 20I7). In theory, the later medieval monastic diet was based around the staples of bread, cheese, vegetables, beans and cereals, with smaller quantities of eggs, fish and meat. The Rule of St Benedict forbade the consumption of the meat of quadrupeds, except by the infirm, but this was relaxed in all except the most austere monastic orders. Cereal carbohydrates were the mainstay, represented by bread and ale; the consumption of meat varied through the year, with more fish consumed on fast days and at Lent (Harvey 1993). The preservation of food remains at archaeological sites is represented principally by animal bones: the presence and varying proportions of different species has come to be recognised as a distinctive food signature of the respective medieval social orders. Monastic diets were usually devoid of large game, in contrast with evidence from castles, and fish remains are more abundant at monasteries than in towns and villages. Some monastic communities favoured beef and mutton 
over pork, according to a study of nine monastic sites in Belgium (Ervynck I997).

The monastic infirmary was generally provided with its own kitchen and served an enriched meat diet in order to rebalance the humours after bloodletting. Waste disposal practices at monasteries were scrupulous by medieval standards and it is rarely possible to identify food remains deriving from specific areas. However, food waste was recovered from the infirmary kitchen excavated at the Augustinian priory of St Mary Merton, from floors and associated pits. Chicken bones were present in large quantities, alongside cattle, sheep and pig, with a few fragments of goose, duck and game birds. A very substantial and diverse assemblage of fish bones was recovered, with the major components including herring, cod and carp (Miller and Saxby 2007: 88). At Paisley Abbey (Renfrewshire), the rediscovery of the Great Drain yielded rare organic deposits dating to the fifteenth century (see Figure 2.2; Dickson I996). Animal bone evidence confirmed a meat-rich diet of beef, pork and lamb, with remains of eel, cod and shellfish. Plant remains included leek, onion, brassica, wheat bran, apple, plum and walnut, all food stuffs found at other medieval sites in Scotland (Dickson and Dickson 2000: 196). There were also rare exotic imports: dried figs from the Mediterranean and nutmeg, likely from Indonesia.

Broad patterns in the consumption of food by different social groups can be refined to the level of individual life experience through isotope analyses of human skeletal tissue. Recent studies have confirmed the importance of marine protein to monastic communities in Britain (Müldner and Richards 2005, 2007). For example, two groups were studied from the Premonstratensian cathedral priory of Whithorn to reconstruct individual life histories and to compare diets and mobility (Müldner et al. 2009). A group of men buried in the presbytery, in close proximity to the likely location of the shrine of St Ninian, were identified as bishops or high-ranking clerics (see Chapter 4): they consumed significantly high levels of marine fish and had migrated to Whithorn from the east of Scotland. Lay-people buried at Whithorn consumed higher quantities of meat and their isotopic signatures showed a predominantly local upbringing.

Archaeobotanical evidence has potential for discerning herbal medical treatment in monasteries and hospitals but caution is needed in interpretation. Plant macrofossils may indicate evidence of food stuffs or seasonings, although the medieval culinary boundaries were blurred: foods such as garlic, onions, honey and almonds were considered to be medicinal. Plants generally perceived as ornamental may have been therapeutic, such as rose, violet and mint. Smells were regarded as material substances in vapour form; when inhaled, they were believed to act on the heart and brain, and could help to rebalance the humours (Rawcliffe 2002: 60). Plants and herbs were used in ointments, laxatives, purges and sedatives, with properties and traditional applications 
recorded in herbals. For example, the Herbal of Syon Abbey (c.1517) lists 700 herbal plants and provides a selection of 450 herbal remedies that make use of around I30 plants, together with animal parts, chemical and mineral materials. The author of the Syon Herbal, Thomas Betson, drew on the herbarium of John Bray and the Breviary of John Mirfield of St Bartholomew's Priory in London, both dating to the late fourteenth century, as well as Dawson's Leechbook, dating to the fifteenth century (Adams and Forbes 2015: 34). Eye complaints are the most common ailment addressed by the Syon remedies, followed by stomach problems, fever, dropsy, gout, toothache and loss of appetite. The symptoms of tuberculosis and cancer are also described, along with problems of conception and lactation, suggesting that the herbal was intended for use both within and beyond the celibate confines of the Bridgettine double monastery.

When extrapolating from archaeobotanical evidence, the argument for medical use is stronger where non-native plants are detected that are likely to have been introduced intentionally to monastic sites. In Norway and Iceland, recent studies have been undertaken of 'relict' plants on the sites of former medieval monasteries. Relict plants are regarded as medieval remnants that have survived at a specific locality since their medieval introduction (Åsen 2009). Historical, botanical and archaeobotanical evidence has been used to identify possible medicinal plants introduced to Iceland, such as madwort (Asperugo procumbens), garlic (Allium oleraceum), caraway (Carum carvi), yarrow (Achillea millefolium) and meadowsweet (Filipendula ulmaria). Archaeobotanical evidence from the excavated Augustinian hospital of Skriðuklaustur includes garlic, stinging nettle and brassicas, possible healing plants not native to Iceland. For example, wild cabbage (Brassica oleracea) was used to treat gout and rheumatism. Well-known medicinal plants from Southern Europe were also found at Skriðuklaustur, such as Artemisia, Sanguisorba and Valeriana officinalis (Kristjánsdóttir et al. 2014: 573).

The monastic regimen placed emphasis on the holistic prevention of illness through techniques of the body including the regulation of diet, physical activity and the practice of blood-letting (Horden 2007). Preventative measures also included care of the body through personal grooming and hygiene: the Syon Herbal provides a number of recipes for soap, both for washing the body and for general housekeeping (Adams and Forbes 20I5: 5I). Archaeological evidence for preventative hygiene includes tools such as ear-scoops and toothpicks. For example, excavations at Dunfermline Abbey (Fife) recovered a bone ear-scoop and an elaborate combination tool of tweezers and ear-scoop in copper alloy (Coleman 1996) (Figure 3.4). Tweezers were common tools for personal grooming but they could also be used for medical depilation or surgery (Bergqvist 20I4). Examples have been recovered from Perth Carmelite Friary (Stones I989), from the infirmary at Merton Priory (Miller and Saxby 


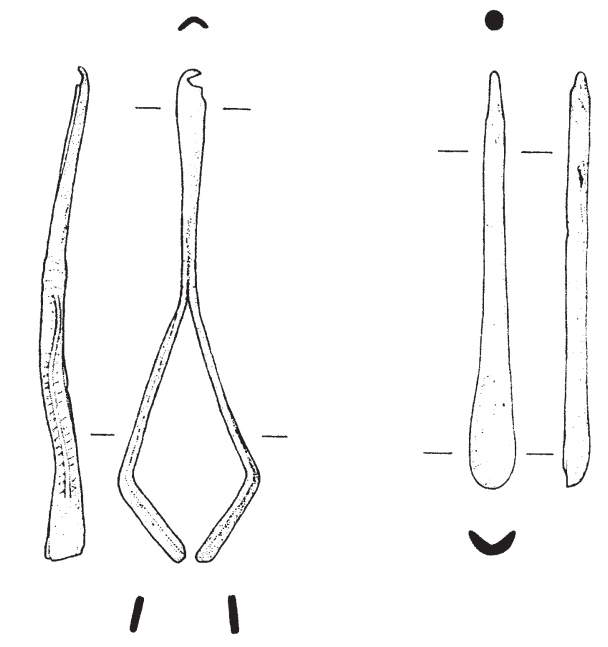

0 $50 \mathrm{~mm}$

\section{$1: 1$}

3.4 Illustration of bone ear-scoop and tweezers excavated from the area of Dunfermline Abbey (Fife). Reproduced by kind permission of Tayside and Fife Archaeological Committee
2007: I28) and from the hospital of St Mary Spital, where five sets of copperalloy tweezers were found (Harward et al. 2019: 275). Small numbers of grooming tools are regularly recovered from monastic sites, for example two ear-scoops and a pair of tweezers from Kirkstall Abbey (West Yorkshire) (Moorhouse and Wrathmell I987: I32-3), tweezers and two toothpicks from Battle Abbey (Sussex), one combined with an ear-scoop (Hare I985: I54, I62), and an earpick and a fine pair of silver tweezers from the nunnery of St Mary Clerkenwell, London (Sloane 20I2: 247).

\section{THE MONASTIC INFIRMARY}

The infirmary of a medieval monastery was generally reserved for the treatment of religious personnel who lived in the monastic precinct. Broader charity was dispensed at the almonry, a complex usually located at the main gates of the monastery, where food was distributed and hospitality and accommodation were provided for pilgrims (Gilchrist 2005: I82). The monastic infirmary housed elderly and infirm monks and those recuperating from illness, injury and the regular round of blood-letting. The well-documented case of Norwich Cathedral Priory reveals that 30 per cent of the monks would have passed through the infirmary in any single year (Rawcliffe 2002: 63). The Norwich infirmary was staffed by four to five attendants, including a keeper of the sick, a servant of those who had been bled, a laundress, a boy and a clerk of the chapel. Specialist members of the laity were retained to treat monastic personnel: a full-time phlebotomist was employed from the fourteenth century and local surgeons were occasionally bought in, together with physicians trained in the Galenic tradition (Rawcliffe 2002: 46-7).

The Bridgettine double house at Syon (Middlesex) was a community of nuns and canons, requiring two separate monastic infirmaries. The Syon Rule emphasises the importance of spiritual and physical care for the sick: the brothers' infirmarer should be 'strong and mighty to lift and move them ... often change ther bedding and other clothes, ley to her [their] plasteres, give hem ther medicyns mynster unto them mete and drynke, fyre water and other 
necessaryes nyght and day after the counsel of the physician'. He should 'exhorte and comforte them (the sick) to be confessyd and receive the sacraments of holy chirche'. The keeper of the sick should not be 'squames [squeamish] to handle hem and wash hem; not angry nor unpaciente, though one have the vomett, another the flyxe, another the frensy'. The Rule confirms that monastic observances were relaxed for the sick but discipline was renewed upon recovery from illness. A nun returning from a period in the infirmary was told to kneel before the abbess to seek penance, saying 'I have transgressed in meat, drink and many other ways, not keeping the regular times of eating, drinking and sleeping and the like, wherefore I do crave mercy and pardon' (Adams and Forbes 20I5: 50-I).

The infirmary complex was usually sited to the east of the cloister for practical, medical and spiritual motives, while the precise location was determined primarily by the need for clean water (Bell I998: 2 II-I3). It was usual for the monastery's watercourse to pass first through the infirmary, in order to provide the purest water to this area. Water was connected with healing through the sacrament of baptism, bringing together the connotations of physical and spiritual cleansing, and recalling Christ's baptism by John the Baptist in the River Jordan (Mark $1: 4-5$ ). According to medieval notions of contagion, infections were transported by mists and noxious smells caused by stagnant water or sewage, and absorbed into the body through the pores. The siting of monastic infirmaries to the east of the cloister stems also from this understanding of contagion, following the Hippocratic notion that the healthiest location was in the east (Bell I998: 220). The scale and complexity of the infirmary varied depending on the size and wealth of the monastic foundation. A larger abbey or cathedral priory was sometimes provided with a second cloister dedicated exclusively to the infirmary, around which were arranged the infirmary hall and chapel and specialist facilities. These might include a kitchen to prepare meat enriched diets, a dining room reserved for meat consumption, private chambers, a blood-letting room, a latrine block and possibly even a bath house, as at Ely and Canterbury Cathedral Priories. The monks of Norwich complained about the lack of tubs and other facilities for bathing and shaving but they benefited from a specialist pharmacy for the infirmarer to prepare medications from exotic ingredients listed in the account rolls. These ranged from the familiar to the exotic: ginger, cinnamon, peony, liquorice, fennel, rice, cloves, mace, cassia, aniseed, white turmeric, poppy seeds, prunes, nutmeg, frankincense and dragon's blood, referring to bright red resin from trees of the Dracaena species (Rawcliffe 2002: 60, 63).

Relatively few monastic infirmaries have been subject to significant archaeological excavation and the investigations that have taken place have focused on the main infirmary hall, rather than on ancillary buildings. We can also draw on architectural survivals such as the late thirteenth-century infirmary 


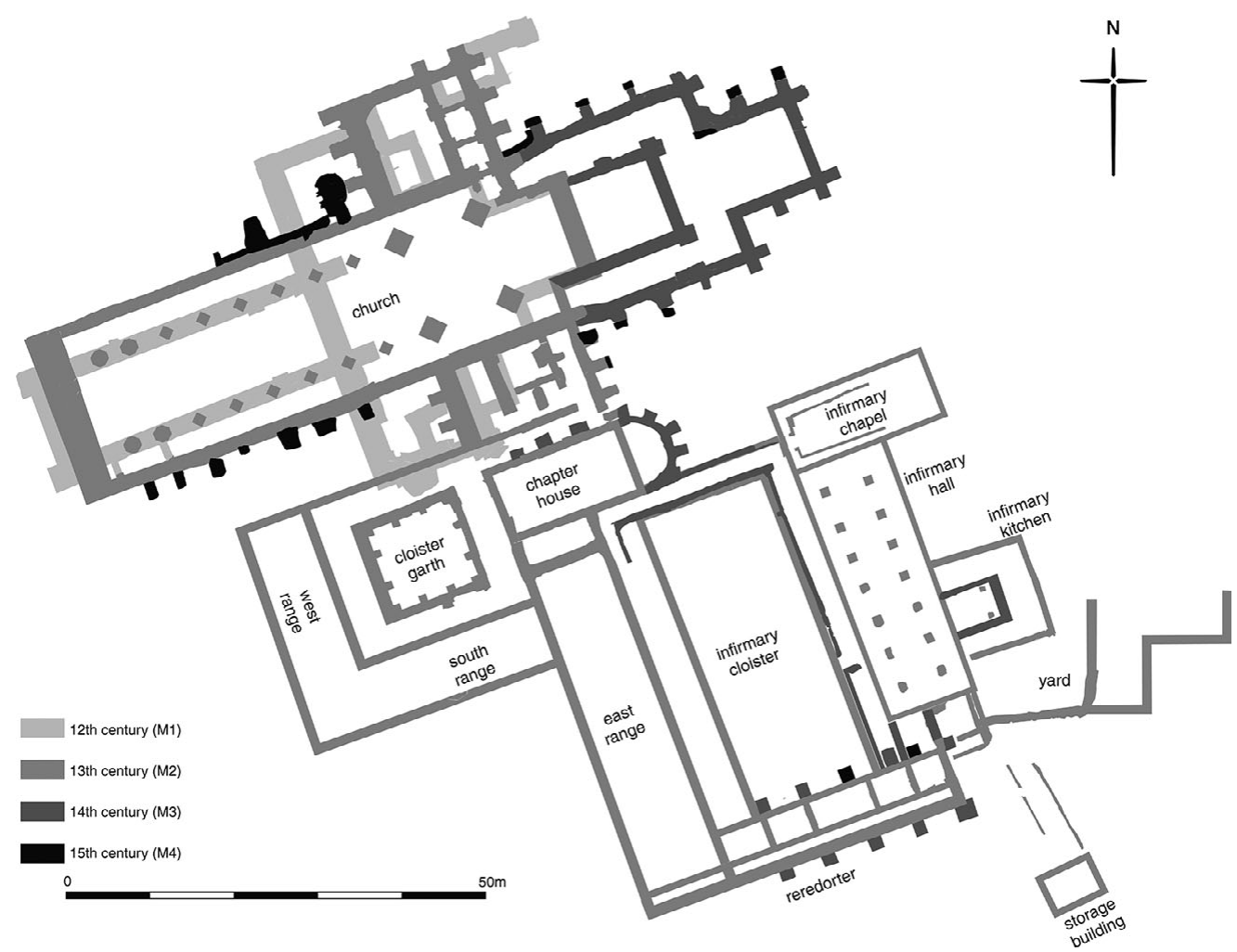

3.5 Plan of St Mary Merton Priory (Surrey). (C) Museum of London Archaeology

hall at St Mary's, Chichester, where the arrangement of the hall and chapel is much like the nave and chancel of a parish church (Gilchrist 1995). The infirmary complex at Merton Priory developed to the southeast of the main cloister, where an infirmary cloister was created between the monastic east range and the infirmary hall (Figure 3.5). A large latrine block was shared by the infirmary and the monks' dormitory and a chapel and kitchen abutted the infirmary hall. The typical arrangement for the infirmary hall was an aisled space opening into a chapel at the eastern end. The beds of the patients were located in the aisles, with the central space kept clear for the circulation of nursing staff. This arrangement is confirmed by archaeological evidence of wear patterns in the floors of infirmary halls: at St Mary Spital, the central area of the earth floor was eroded; at Merton, the floor tiles were more heavily worn in the centre of the hall (Miller and Saxby 2007: 125-6). The chapel may have been screened from the hall but direct visual access to the altar was important for the patients to benefit from the healing power of the Eucharist. Windows would have been glazed and fireplaces were sometimes provided, as at Merton, where there was also evidence for a cupboard in the western wall, perhaps a dispensary for medicines. 
The infirmary hall at the Tironensian abbey of Kelso in the Scottish Borders was excavated to the southeast of the main cloister. The central space and eastern aisle were recorded, showing an arrangement of alternating circular and octagonal piers, closely comparable to the infirmary hall at Norwich Cathedral Priory. Kelso's infirmary was aligned north-south, rather than the more typical east-west, a pattern also seen at Waltham (Essex), Fountains and Rievaulx Abbeys (North Yorkshire). An impressive assemblage of cooking pots and jugs was recorded, confirmed by petrological analysis to have been made from local clays. The importance of lighting is illustrated by the find of a green-glazed cresset lamp, a form which is rare in Scotland (Tabraham I984). In the later Middle Ages, monastic infirmary halls were often modified to create more private spaces for patients and special dining rooms were developed to accommodate the enriched meat diet. These private chambers were created by subdividing the aisles of the infirmary hall into separate compartments, as evidenced at Merton Priory, where single rooms were created in the aisles in the late fourteenth century (Miller and Saxby 2007: 126). Upper floors were sometimes inserted to provide additional spaces: at Norwich, a floor was inserted in the fourteenth century to provide a dining room on the ground floor and a private chamber above (Gilchrist 2005: I80). It was not uncommon for the comfortable spaces of the infirmary to be requisitioned by senior monastic officials, with private apartments developing at several Cistercian abbeys and cathedral priories (Gilchrist 2005: I8I).

Arrangements in an Augustinian hospital priory are vividly illustrated by St Mary Spital in London, which shows both expansion over time and the accommodation of separate social groups within the community (Figure 3.6). Hospitals were commonly located on the edges of towns, near the walls and on main roads and bridges, in order to cater for travellers and pilgrims, and due to the greater availability of suburban land (Rawcliffe 2005). The priory of St Mary Spital was founded to care for pilgrims, sick poor, orphans and women in childbirth. The foundation of II97 was for a small hospital of twelve to thirteen beds arranged in a simple rectangular hall. The re-foundation of the hospital in

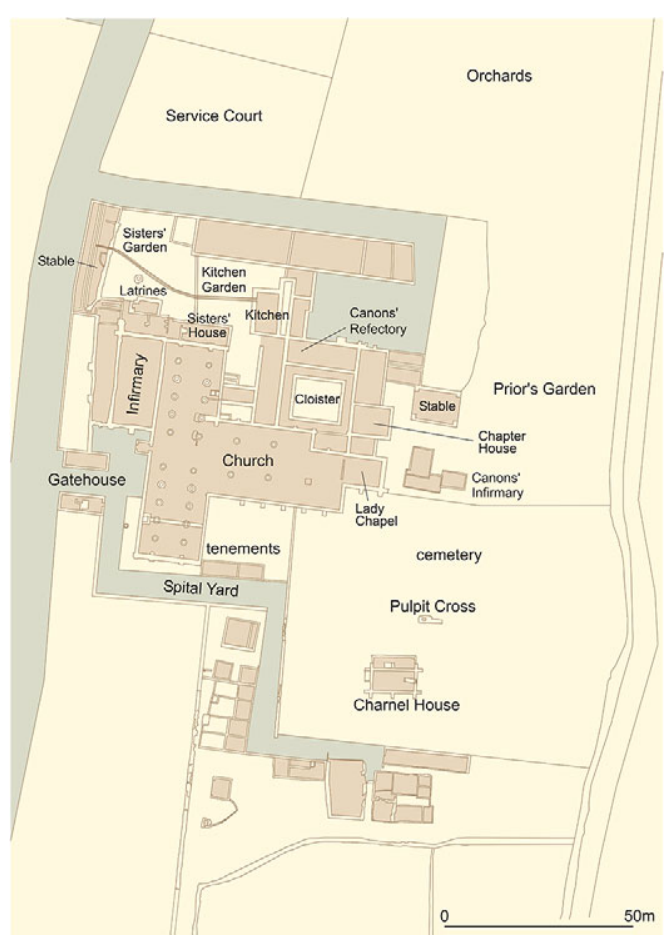

3.6 Plan of St Mary Spital, London. (C) Museum of London Archaeology 

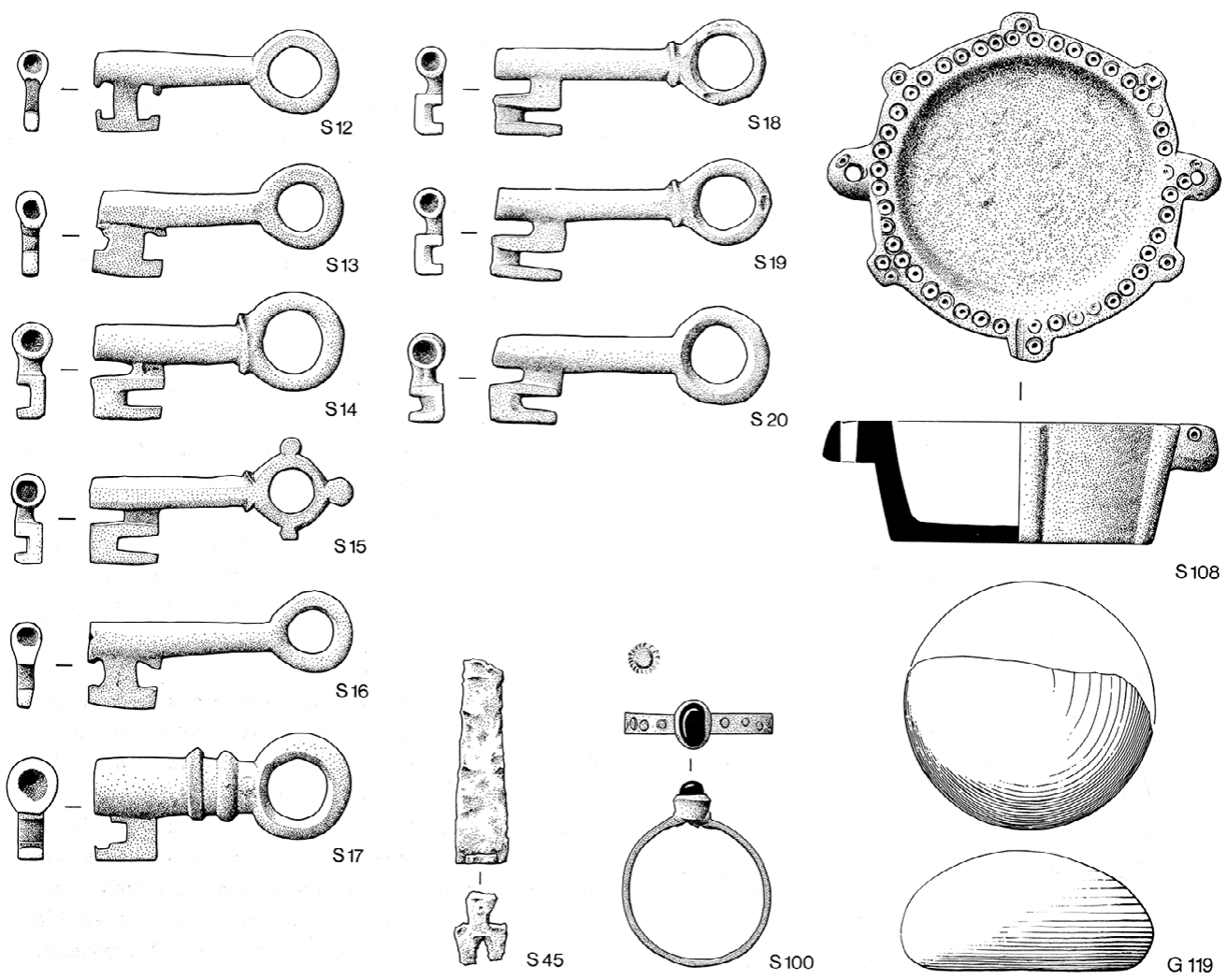

3.7 Small finds from the infirmary hall at St Mary Spital, London. (C) Museum of London Archaeology

I235 increased the number of beds to sixty. Both men and women were accepted by the hospital and they were segregated by splitting the infirmary into a T-shape, with the chapel in the centre and men and women housed in separate wards (Connell et al. 20I2; Thomas et al. I997). The T-shape was used for other mixed-sex hospitals such as St John the Baptist, Canterbury (Gilchrist I995: 2I). Large assemblages of keys were recovered from St Mary Spital (Figure 3.7) and also from the hospital of St Bartholomew, Bristol (Price with Ponsford I998), perhaps indicating that lockers were provided to store patients' personal belongings. A new, two-storey infirmary was built at St Mary Spital c.I280, and the earlier hall was converted into a very large church. It is likely that men and women were segregated on different floors, as they were at SS John the Baptist and John the Evangelist, Sherborne (Dorset) (Gilchrist I995: 2I). A two-storey extension was added to St Mary Spital in the fourteenth century: at its height, the hospital catered for I80 beds (Thomas et al. I997: IO3-5).

The patients were cared for by a nursing staff of six to seven lay-sisters who were accommodated in a house next to the infirmary, built initially in timber 
and rebuilt in stone in the late fourteenth century. This housed the sisters' dormitory and refectory. These women nursed the sick and carried out daily chores: the main roles of hospital nurses were preparing meals for the sick, keeping the lamps lit in the infirmary, and changing and laundering the bed sheets (Rawcliffe I998: 58). The sisters at St Mary Spital had their own private garden: finds from this area included thimbles and bone needles that the sisters would have used in mending, and personal dress accessories including buckles, a finger ring and possible headdress pins (Thomas et al. I997: I09-I0). Female artefacts found from other contexts in the hospital include three wire supports for headdresses (Harward et al. 20I9: 274). Each lay-sister would have nursed up to thirty beds at St Mary Spital, with perhaps two to three patients in each one; a ratio of one nurse for up to sixty to seventy patients. Nursing sisters took the customary monastic vows of poverty, chastity and obedience, and were expected to dress in the most humble attire (Rawcliffe I998: 48). Hospital ordinances frequently specified that virgins, chaste widows or women over the age of fifty should be selected for nursing sisters. They greeted and washed new patients when they arrived at the hospital, and in due course, washed and prepared the dead for burial in the hospital cemetery. Nursing was seen as an active spiritual vocation for women, but by the later Middle Ages, salaried nursing servants were beginning to replace nursing sisters (Rawcliffe I998: 64).

The Augustinian canons of St Mary Spital were provided with a full monastic cloister to the north of the church, complete with dormitory, refectory, chapter house and their own private kitchen and infirmary. The canons' infirmary shows some signs of economy: it was a timber-framed building on stone foundations and it had no piped water supply (Harward et al. 20I9: I54). However, the difference in status between the sisters and canons is all too evident in the accommodation and facilities provided for them. The higher quality of the canons' accommodation reflects medieval attitudes towards gender but also the greater value that was placed on the spiritual administrations of the canons, over the practical care for the body that was provided by the nursing sisters.

\section{THERAPEUTIC CARE}

Archaeology provides new evidence for the diagnosis and treatment of the sick in medieval monastic infirmaries and hospitals. The practice of more academic medicine is confirmed by the presence of fragments of urinals, or jordans, the common symbol of the medieval physician. Physicians used glass urinals to examine urine samples for consistency, colour, clarity and odour, which signified particular diseases or states of health. Uroscopy was the mainstay of the physician's diagnostic repertoire; the technique was closely associated with astrology, which influenced the diagnosis and the recommended cure 


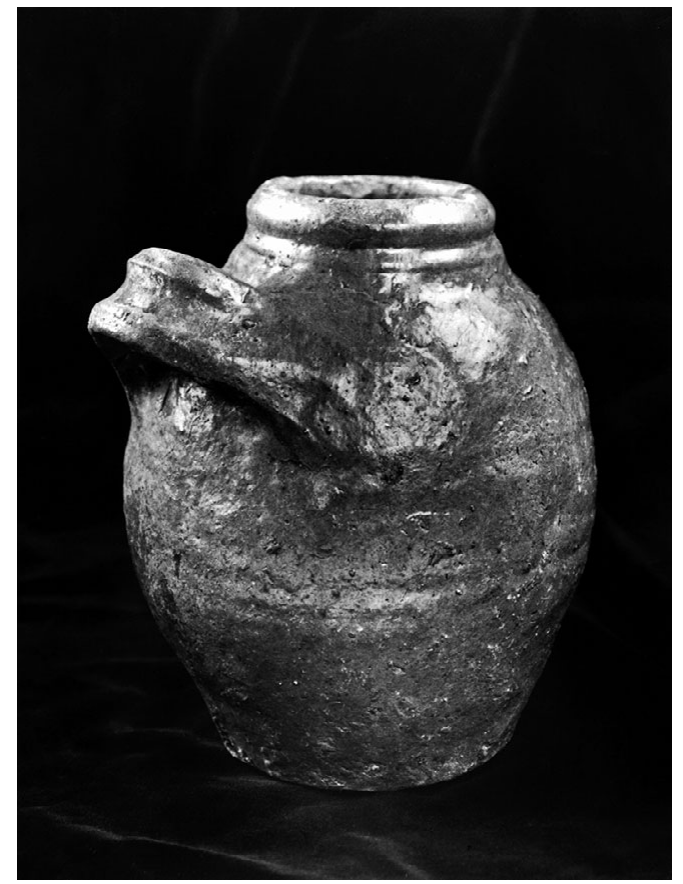

3.8 Ceramic urinal from Paisley Abbey's Great Drain (Renfrewshire). (C) Crown Copyright: Historic Environment Scotland
(Rawcliffe 2006). The extensive excavations at St Mary Spital located just two fragments of glass urinals dated to the fourteenth century (Thomas et al. I997: III). For comparison, two were recovered from the infirmary drain and latrine block at $\mathrm{St}$ Mary Merton (Miller and Saxby 2007: I28), five from the nunnery of St Mary Clerkenwell (Sloane 2012: 245) and twelve from the eastern range of Battle Abbey (Hare I985: I4I-2). The use of uroscopy in monastic contexts is also reflected in monastic book ownership and production; for example, the Syon Herbal has a full chapter in Latin on the use of urine for diagnosis, particularly in relation to women's health (Adams and Forbes 20I5). In Scotland, only ceramic urinals have been reported, including a complete example recovered from the Great Drain at Cistercian Paisley (Malden 2000: I75) (Figure 3.8), one from Benedictine Coldingham (Scottish Borders) (Laing I97I-2) and three from Cistercian Glenluce (Dumfries and Galloway) (Cruden I950-I). Stephen Moorhouse suggested that ceramic urinals were not intended for medical purposes, but were instead used to separate liquid and solid human waste, with urine retained for industrial uses such as tanning. He noted the concentration of such vessels near latrine blocks at Melrose Abbey (Scottish Borders) and Kirkstall Abbey and explains them as accidental losses when emptying waste (Cruden I952; Moorhouse I993: 129). The absence of glass urinals in Scotland must have severely impeded the practice of uroscopy: a translucent vessel was required to see the colour of the urine and to observe sedimentation. Vessel glass is rarely recovered from Scottish medieval contexts although a few fragments have been reported from Perth Whitefriars (Derek Hall, pers. comm.). There is no evidence for the manufacture of glass in Scotland until the early seventeenth century, and imported glass wares are poorly preserved in Scotland's acidic soils.

Other specialist medical objects from monastic sites include spectacles, indicating the diagnosis and attempted correction of vision defects (Figure 3.9). An elaborate pair of bone spectacles was excavated from St Mary Merton, carved in the form of ecclesiastical tracery. Spectacles have also been recovered from Battle Abbey, the Dominican friary at Chester, Wells Cathedral, the 
Bridgettine abbey at Syon and Alvastra in Sweden (Miller and Saxby 2007: 127). The importance of literacy in the monastic lifestyle would have resulted in a high value being placed on the correction of sight impairments. This is confirmed by the prominence of eye conditions in the Syon Herbal, representing the most frequently cited ailment in Syon's herbal recipes (Adams and Forbes 2015: 40). Medieval burials sometimes provide evidence of other types of therapeutic device. The great majority of Christian burials were simple interments of the naked corpse in its shroud, with no clothing or grave goods included. Very

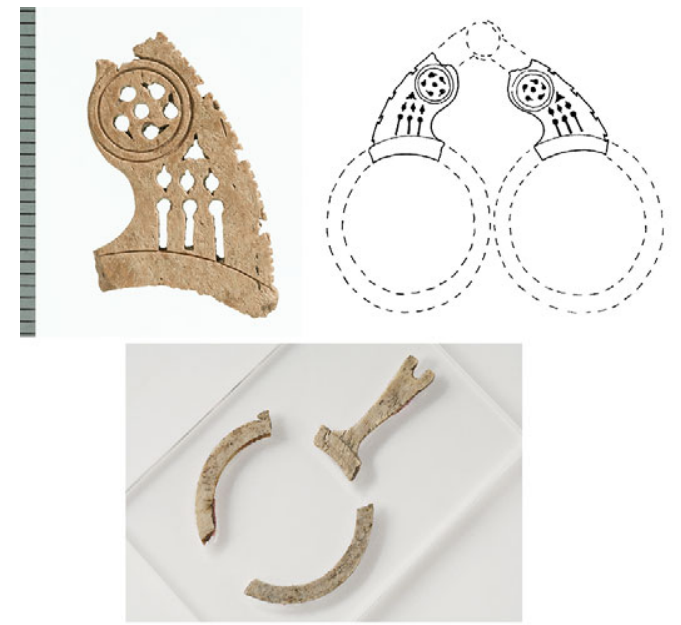

3.9 Bone spectacles from St Mary Merton (Surrey; (C) Museum of London Archaeology) and Alvastra monastery (The Swedish History Museum) rarely, however, healing objects or prosthetics were left in place on the corpse after it had been washed and prepared for burial (see Chapter 4, for interpretation in relation to spiritual transformation of the body). For example, a bone paternoster bead was used as a tooth 'filling' in a medieval burial from Denmark (Møller-Christensen 1969). Three main types of therapeutic object have been identified in medieval burial contexts: copper-alloy plates used to protect and heal joint injuries or disease, other metal supports for limbs, and hernia trusses (Gilchrist and Sloane 2005: IO3-4) (Figure 3.IO).

Pairs of support plates have been found with individuals from St Andrew's Gilbertine priory in York and from the leprosarium of St Mary Magdalene in Reading (Berkshire). The older male from York had a rotary fracture of the right knee: the plates were bound to the joint to provide support, fixed by stitched leather coverings (Knüsel et al. I995). The female from Reading had a badly necrosed humerus; the plates contained dock leaves, perhaps applied as a poultice to the infection. Single plates have been found with burials at St Mary Stratford Langthorne (Essex), Pontefract Priory (West Yorkshire), St Mary Merton and St Mary Spital, where leaves were also found adhering to the plate. The dates of the burials range from the twelfth to the mid-fourteenth century. Contemporary sources confirm the medical use of herbal ligatures, for example cited in a healing miracle associated with St Æbbe (Bartlett 2003: xlviii). At Varnhem Abbey in Sweden, an almost pure copper plate was used to stabilise a possible sword or axe wound on a humerus (Hallbäck I976-7: 80); similarly, a copper plate was found associated with the upper arm of a burial at the church of Vrasene, Belgium (Janssens 1987). A different type of support was present at St Mary Spital, where a plate of lead sheeting was wrapped 

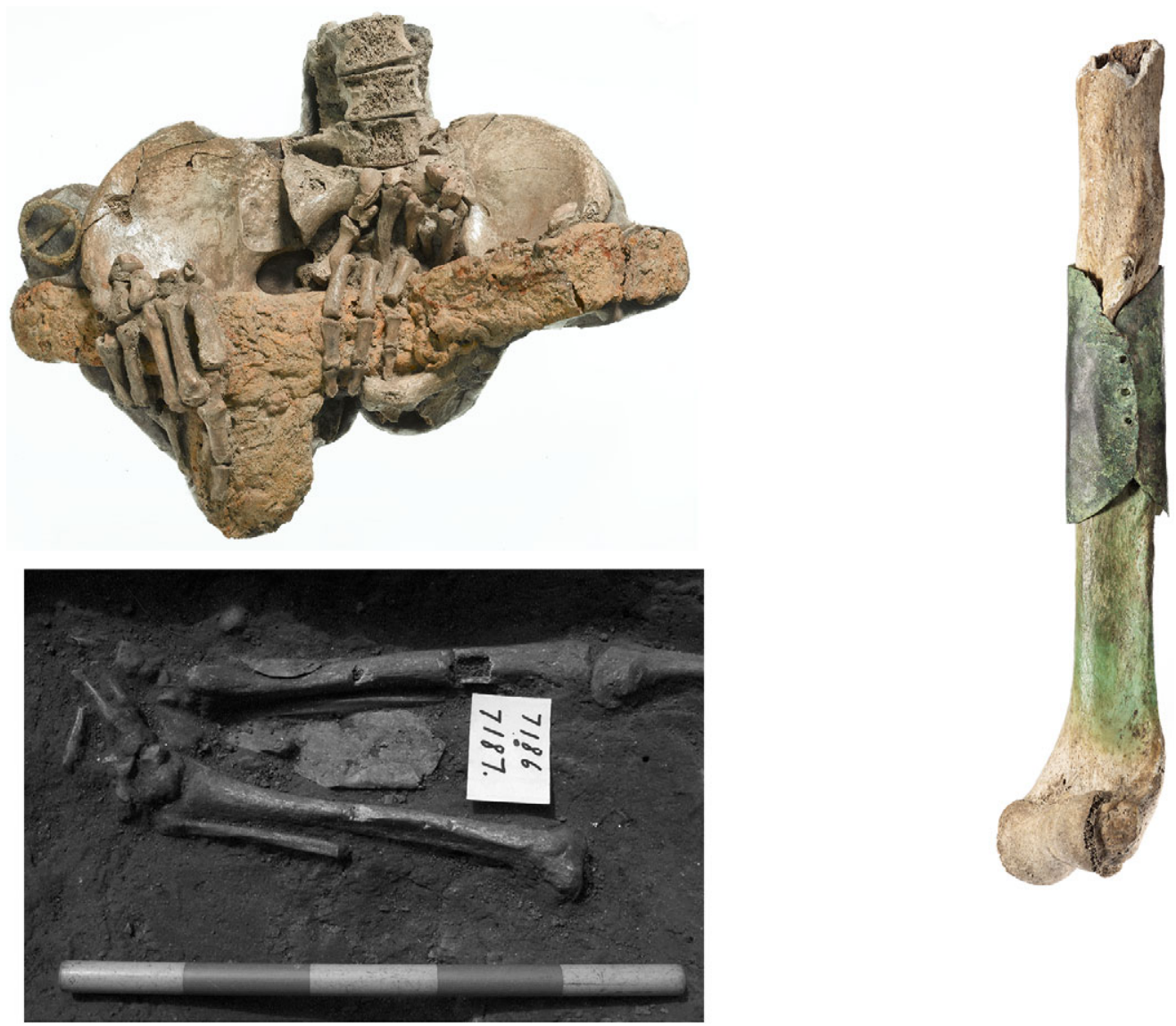

3. I o Therapeutic devices found in burials at medieval monastic sites: Hernia truss from St Mary Merton (Surrey; C Museum of London Archaeology), lead sheeting around right shin of female from St Mary Spital, London (C) Museum of London Archaeology), bone with copper plate from Varnham monastery (photograph by Ola Myrin, The Swedish History Museum).

around the shin of a female who showed active periostitis of both legs. The lead sheet contained brown animal hair on its inner face, perhaps indicating a poultice, or alternatively, a charm of some kind (Connell et al. 20I2: 208). Hernia trusses are known from early medieval graves in Britain and Europe (such as Llandough: Redknap 2005) but just one example has been identified from a later medieval monastic cemetery in Britain. An older male excavated from the north transept of the church at Merton Priory was found with a belt in situ, worn low on the pelvis, and interpreted as a support for a scrotal hernia. The Merton belt is made from iron and was bound to the body with woven textile and fixed with buckles (Miller and Saxby 2007: IOI, 230). Both hands of the skeleton were clutching the strap, with some of the fingers laced over the belt and some behind it.

Burials sometimes contain evidence of certain materials believed to possess therapeutic or 'occult' properties (see Chapter 4). The materials of the copper 
plates from Varnhem and Vrasene and the lead sheet from St Mary Spital may have been selected for their therapeutic or humoral properties. Lead was also used in making amulets for healing or protective use (Gilchrist 2008: 125). Mercury, also known as quicksilver, was thought to have a cold, wet complexion; it was valued for its regenerative and purgative qualities and for its capacity to destroy infected flesh and remove unsightly blemishes (Rawcliffe 2006: 224). Mercury and cinnabar (mercury sulphur) were used to treat skin diseases such as scabies and skin lesions associated with leprosy and syphilis (Connell et al. 20I2: 209). High levels of mercury have been found in the bones of skeletons excavated from Danish, German and Icelandic medieval cemeteries; analysis of associated soil samples indicates that the high mercury levels were not caused by post-mortem diagenesis (Rasmussen et al. 20I3, 20I5). At the Icelandic monastic hospital of Skriðuklaustur, eleven individuals exhibited elevated mercury concentrations and showed skeletal changes indicative of infection, including treponemal disease. Given the strong archaeological evidence for medical treatment at Skriðuklaustur (discussed below), it is likely that the raised mercury levels in these individuals resulted from medical therapies. However, exposure to mercury may also have resulted from use of cosmetics, ink or vermilion pigment, made scarlet red from ground mineral cinnabar. There were some individuals with raised mercury levels at Skriðuklaustur who showed no signs of pathological lesions, including a female buried in a prestigious location within the church. It has been suggested that she may have been a medical practitioner within the hospital, who would have been exposed to mercurial vapours while treating patients with mercury rubs (Walser et al. 20I8). Mercury droplets have also been found on the skeleton of a young female buried in Exeter Cathedral Green in the late Middle Ages. Her skeleton reveals that she suffered from scoliosis and possibly miliary tuberculosis. The droplets were found on her right hip bone, causing blackening of the bone. It is possible that the droplets came from a medicinal vial hung from her waist that has since disintegrated (Kingdom, forthcoming).

Specialist surgical instruments (Figures 3.II and 3.I2) are remarkably rare finds in Britain, with no confirmed examples surviving from monastic sites, although two bronze objects from Glenluce Abbey are perhaps surgical hooks (Cruden I950-I). General purpose objects such as scissors and knives may have been put to medical use: for instance, thirty-four knives and blade fragments were excavated from the hospital of St Giles by Brompton Bridge (North Yorkshire) (Cardwell I995: I94-6). These could have been employed for medical purposes, such as phlebotomy, preparing medicinal ingredients and cutting up dressings; equally, they could have been used for domestic and craft-working activities. The paucity of specialist instruments from Britain can be contrasted with the recently excavated site of Skriðuklaustur, a remote Icelandic hospital and monastery following the Augustinian Rule. Medical 

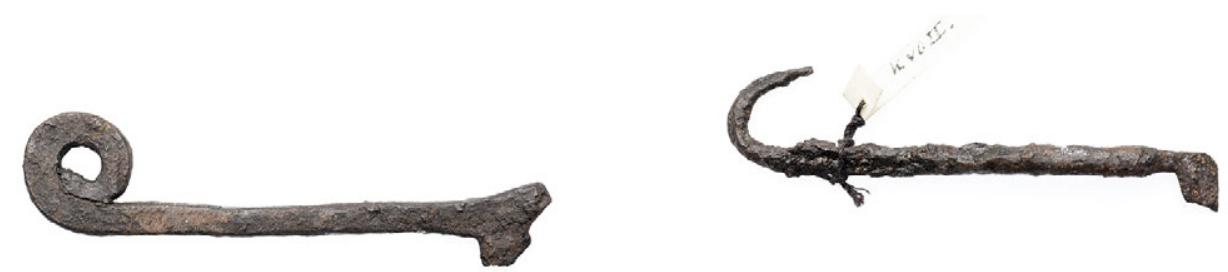

||||||||||||||||||||||||||||||||||||||||||||||||||||||||||||||||||||||||||||||

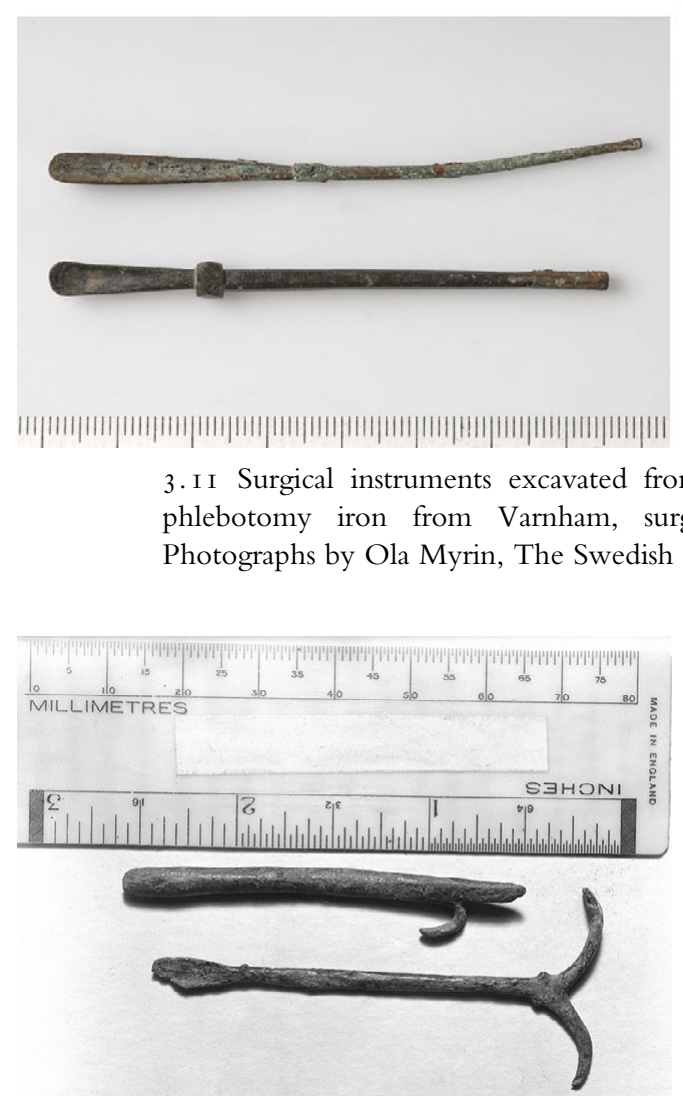

3. I 2 Possible surgical hooks from Glenluce Abbey (Dumfries and Galloway). (C) Crown Copyright: Historic Environment Scotland care is indicated by the presence of implements for surgery or suturing, together with medical phials (Kristjánsdóttir 20I0). The Cistercian monasteries of Alvastra and Varnhem in Sweden produced a range of medical objects including scalpels, phlebotomy knives, a cautery, a surgical hook, spatulas for applying medicament, probes and forceps for exploring wounds, and curettes for cleaning wounds (Bergqvist 20I4: 9I). The negative archaeological evidence for surgical instruments from Britain seems to confirm that surgery was not routinely practised in monastic infirmaries. Surgery was readily available to medieval religious, but it was either performed elsewhere, or visiting surgeons were scrupulous in their care and retention of instruments. Surgery would not have been performed in hospital wards which contained a chapel, due to the prohibition against shedding blood in a consecrated space. The archaeological evidence from Iceland and Sweden may indicate that the distinction between academic and empirical medicine was not as strictly drawn in Scandinavian culture, and that surgery was performed more routinely in monastic contexts. 
The types of food vessels used in infirmaries may have been selected to help nursing staff in feeding the sick. The ceramic cooking pots and jugs recorded at both St Mary Spital and St Mary Merton were standard forms, with one possible exception. Both sites produced evidence of ladles in blue-grey ware that are rare in London. The ladles show external sooting, indicating that they were placed in direct contact with fire (Thomas et al. I997: 59). It has been suggested that the ladles may have been used to reheat and serve individual portions of food for the patients. One of the ladles from Merton was subjected to subsurface residue analysis which indicated the presence of fats/oils and cereals (Miller and Saxby 2007: I28). Specialist vessels were also suggested at the leper hospital of St Nicholas in St Andrews (Fife), where an unusual form of flat-based open bowl was identified in the assemblage of Scottish East Coast Gritty Ware (Hall I995: 60). The bowls were green-glazed internally and externally smoke-blackened - again, perhaps indicating the heating of individual portions by direct contact with the hearth.

A large assemblage of wooden bowls was found at St Mary Spital, some of which were shallow dishes that may have been used to feed the infirm (Thomas et al. I997: 59-6I) (Figure 3.I3). One was an unusual double bowl that could be turned over and used again from the other side, perhaps for a second course. The wide rims would have helped to avoid spillage and may have been designed specifically for a second person to hold steady by the foot while an infirm patient was fed. Personal feeding bowls may have been common at medieval hospitals. During excavations at St Mary Magdalen, Winchester, fragments of two pottery vessels were found in the grave of an individual with leprosy who exhibited severe facial deformities. These have been interpreted as personal food bowls, perhaps indicating assisted feeding or the use of dedicated utensils (Roffey and Tucker 2012: 176).

There is growing archaeological evidence for the use of herbal medicine in the treatment of the sick. Albarelli, or drug jars, have been identified at a number of monastic sites: these are specialist vessels imported from the Mediterranean containing exotic drugs for the dispensary. Possible examples have been reported from the Carmelite friary in Linlithgow (West Lothian)

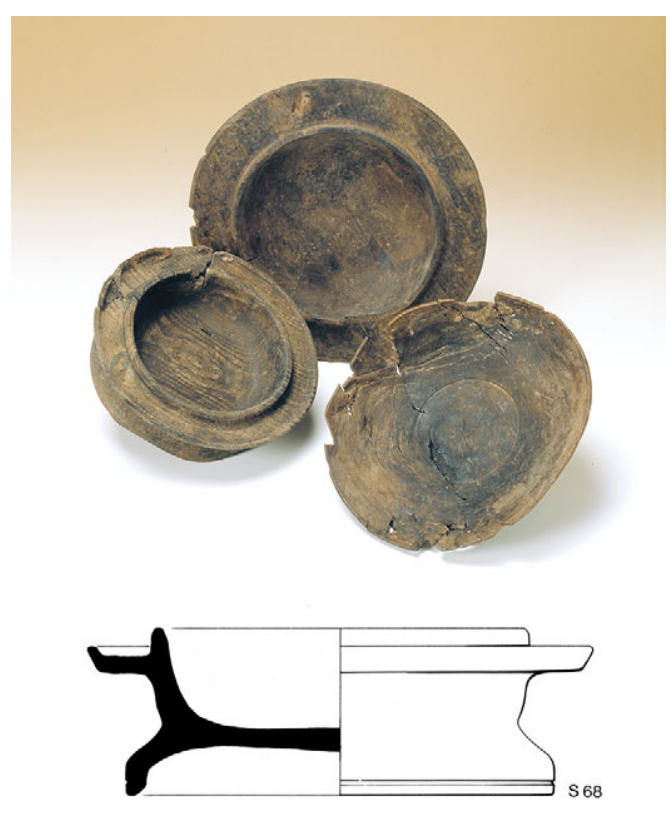

3. I 3 Food vessels from St Mary Spital, London: wooden bowls and illustration of double bowl possibly used to feed the infirm, max. diam $170 \mathrm{~mm}$. (C) Museum of London Archaeology 

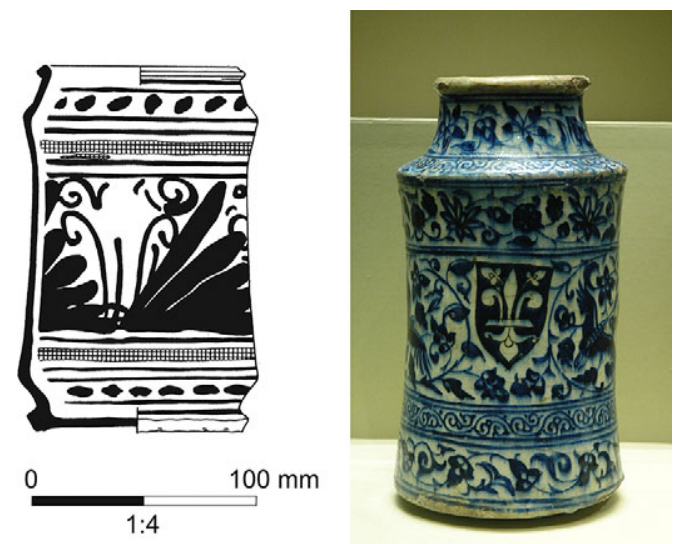

3. I 4 Illustration of albarello excavated from St Mary Clerkenwell, London, height I64 mm (C) Museum of London Archaeology), and a similar example in the Louvre Museum (photograph by Marie-Lan Nguyen / Wikipedia / Public Domain).
(Stones I989), from Merton Priory (Miller and Saxby 2007: I28), and a near complete example from the nunnery of St Mary Clerkenwell (Figure 3.I4), dated to the second quarter of the sixteenth century (Sloane 20I2: 238). Chemical analysis of a jar fragment from Glastonbury Abbey (Somerset), dating to the early fifteenth century, has proven its origins in Tuscany (Blake 2015: 270). Two albarelli were excavated from the hospital of St Mary of Ospringe (Kent): one jar was Malaga Ware with a thin, tin glaze enamel with cobalt blue decoration, dating to the fourteenth century; the other had a deep yellow glaze and came from Dissolution levels (Smith I989). There were no imported drug jars from the hospital of St Giles by Brompton Bridge but the ceramic assemblage was dominated by jars in domestic wares (37 per cent of the total pottery assemblage) (Cardwell i995: I69-79).

Herbal plants were also grown in monastic gardens and collected from the local environment to be processed for medicinal use. Stone mortars from monastic sites were used for the preparation of foods and medicines, for instance three mortars in Purbeck marble were excavated from the nunnery of St Mary Clerkenwell (Sloane 20I2: 245), and a very large assemblage of ten mortars from St Mary Spital in Purbeck-type marble and shelly limestone (Harward et al. 20I9: 264-7). Monastic account rolls sometimes confirm the purchase of distilling equipment and it is often assumed that this equipment was used to transform herbs and flowers into perfumed oils, essences and waters. For example, the infirmarer at Norwich Cathedral Priory recorded the regular purchase of glass phials and distillation equipment in the fifteenth century, in addition to the purchase of a large alembic and the construction of a clay furnace to be fired by peat (Rawcliffe 2002: 6I). Medical texts included recipes for distillation: notably, the early sixteenth-century Syon Herbal contained a complete chapter on herbal essences preserved in distilled alcohol, and the late fourteenth-century Breviary of John Mirfield of St Bartholomew's Priory, London, featured over fifty different distilled waters (Adams and Forbes 20I5: 36). Aristocratic households also practised distilling, as evidenced in a late fifteenth-century manuscript associated with the Scropes of Bolton, the Berkeley Castle Muniments Select Book 89 (Voigts and Payne 20I6). The first part of the manuscript comprises distillation recipes, while the second combines medical and culinary recipes, some of which required distillation. The recipes 

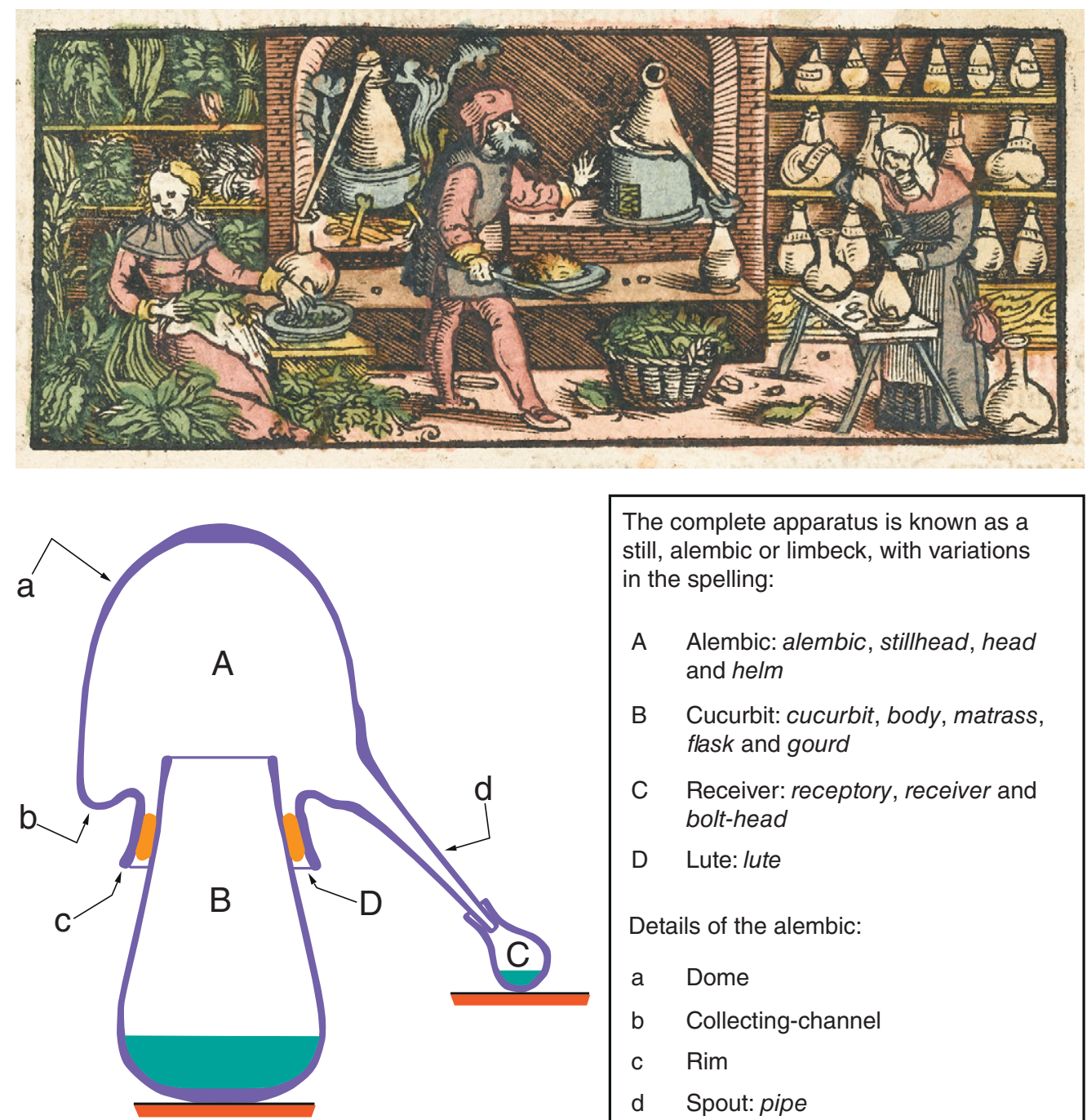

The complete apparatus is known as a still, alembic or limbeck, with variations in the spelling:

A Alembic: alembic, stillhead, head and helm

B Cucurbit: cucurbit, body, matrass, flask and gourd

C Receiver: receptory, receiver and bolt-head

D Lute: lute

Details of the alembic:

a Dome

b Collecting-channel

c Rim

d Spout: pipe

3. I5 Diagram of distillation equipment and a I6th-century drawing showing similar equipment in use. After Moorhouse I972 (C) Sarah Lambert-Gates and Wellcome Collection, Public Domain

demanded exotic and costly ingredients, such as saffron, cinnamon, cloves, ginger, nutmeg, black pepper, caraway, cumin, camphor, musk and ambergris.

Distillation is a chemical process that harnesses the different boiling points of liquids in order to concentrate them for the production of fragranced oils and perfumes, strong alcohols and mineral acids (Booth 20I6). Archaeological evidence for distillation in Britain dates from the thirteenth to fourteenth centuries onwards, comprising glass or ceramic alembics (stillheads), glass or ceramic cucurbits (distilling bases on which the alembic sat) and ceramic or glass flasks and phials that served as receivers for the distillate (Moorhouse I972; Tyson 2000) (Figure 3.I5). A liquid was boiled in the lower vessel, the 
cucurbit, and the vapour condensed in the domed head of the upper vessel, the alembic; the resulting liquid drained through a collecting channel into the receiver, termed the 'receptory' in vernacular documents. This technology remained unchanged until the development of metal stills in the seventeenth century (Booth 20I6). Christopher Booth has surveyed the material culture evidence for the practice of chemistry published from twenty-three excavated monastic sites in Britain, distinguishing between the processes of distillation, cupellation and sublimation (Booth 20I7). Distillation was used to produce alcohol and mineral acids; cupellation yielded silver from the melting of composite ores or man-made alloys; and the process of sublimation was used to transform a solid into a gas, for example mercury, sulphur or antimony, and is likely to indicate alchemical practice (Booth 2017: 197, 206).

The largest monastic assemblage of glass and associated ceramics for distilling came from Pontefract Priory, with significant concentrations recovered from Selborne Priory (Hampshire), Kirkstall Abbey and St Mary Spital. Some sites have yielded only ceramic evidence, such as the relatively poor Cistercian abbey at Hulton (Staffordshire) (Klemperer and Boothroyd 2004: 176) and wealthy Glastonbury Abbey, which has four possible cucurbits amongst its ceramic assemblage (Kent 20I5). Many monastic excavations have produced one or more fragments of alembics or cucurbits, confirming that distilling was a widespread practice from the fourteenth century onwards (e.g. the hospital of St Mary Magdalene at Partney, Merton Priory, Battle Abbey, Hailes Abbey (Gloucestershire), Northampton Grey Friars and Leicester Austin Friary: Atkins and Popescu 20I0; Moorhouse 1972, I993; Hare I985: I42; Oakley I978; Woodland I98I). Excavations at Sandal Castle (West Yorkshire) produced a substantial assemblage of distillation equipment, the remains of a workshop dumped in the castle's barbican ditch (Moorhouse I983). Sandal Castle and Pontefract Priory are located in close proximity and it is possible that knowledge was shared between monastic and secular households, resulting in regional clusters of distilling workshops. The scarcity of glass in medieval Scotland (discussed above) is likely to have inhibited the practice of medical distilling. To date, only three ceramic alembics have been evidenced from medieval Scotland, including a green-glazed example from Jedburgh Abbey (Scottish Borders) (Cruden I955-6: 77; Moorhouse 1972), and one in Scottish redware excavated from the site of Aberdeen Franciscan Friary; ICP analysis confirmed that it was manufactured in the Perth area (Hall et al. in prep.). A basal fragment from the leper hospital of St Nicholas in St Andrews represents the first archaeological evidence of distillation at a leprosarium (Hall I995).

What types of distillates were produced at medieval monasteries? Residue analysis on an alembic from demolition deposits in the infirmary drain at Merton Priory indicated the distillation of a fermented product (Miller and 
Saxby 2007: 128). This could have been used for distilling wine into aqua vitae, which had a wide range of medicinal uses including relieving toothache, expelling poison and treating cancer (Moorhouse I972, I993). But not all distillation aimed to produce inert herbal liquors or perfumed oils: medical recipes and archaeological analysis of residues confirm that distillation was used in combination with the processing of chemicals and minerals. Excavations at St Mary Spital have produced evidence for three discrete areas of distillation (Figures 3.I6 and 3.17), each of which employed heavy metals such as lead (Harward et al. 2019: I64-72). A cucurbit with a lead rich residue came from an early fourteenth-century deposit in the canons' infirmary at St Mary Spital. In the later fourteenth century, a possible pharmacy was built to the east of the canons' infirmary. This timberframed building was identified as a distilling workshop on the basis of peatburning hearths covering its floor; these

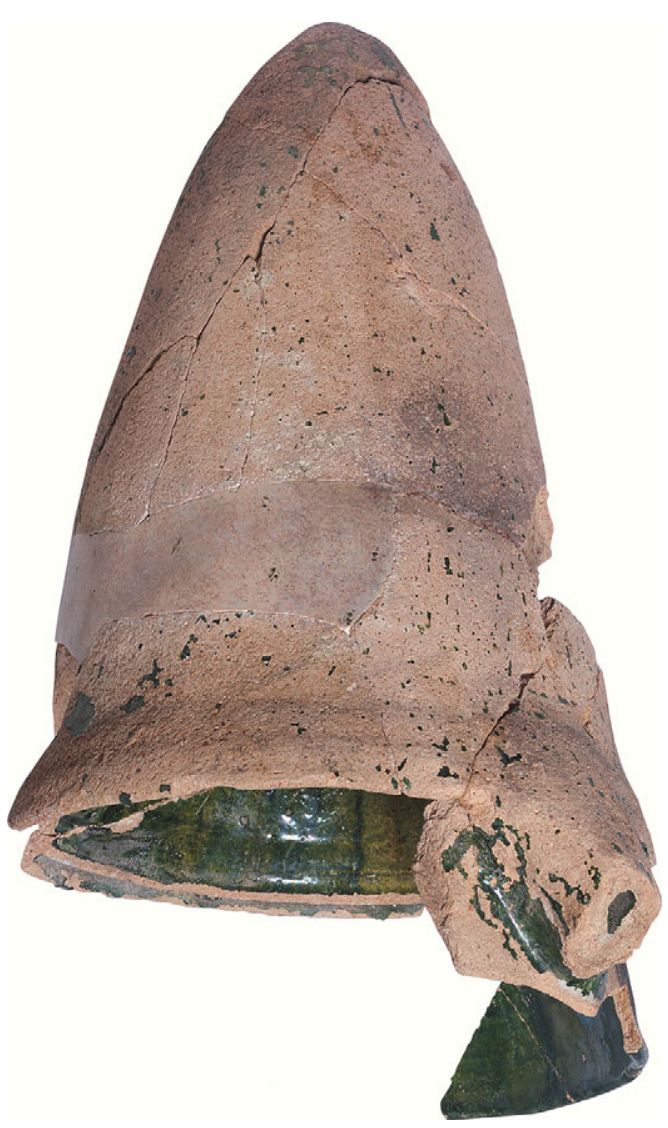

3. I6 Ceramic alembic from St Mary Spital, London, height $290 \mathrm{~mm}$. (C) Museum of London Archaeology are likely to be the remains of clay furnaces, a common industrial method employed by distillers and recorded in the infirmarers' accounts from Norwich Cathedral Priory (noted above). Residual evidence of arsenic, lead, copper and iron was detected in the building and a nearby pit yielded ceramic and glass distilling vessels. Tests on residues within the vessels revealed the presence of mercury, lead, iron, arsenic and copper; one deposit also contained calcium and phosphorus, possibly from a crushed bone. This building was used for specialist production up to the mid- or late fifteenth century. Another workshop using distillation was discovered in one of the tenements south of the cemetery at St Mary Spital, which contained a number of rooms with industrial hearths against the walls; a phial of mercury was found in the floor of a nearby structure. Six glass cucurbits were recorded from St Mary Spital, in addition to ceramic alembics, and bottles and kitchenware were reused for industrial or pharmaceutical processes. A silver litharge cake was also found in a building dating to the fifteenth century, which may have been used for medical or industrial applications (Harward et al. 2019: 178-9). Analysis of vessels from Pontefract and Selborne Priory also 


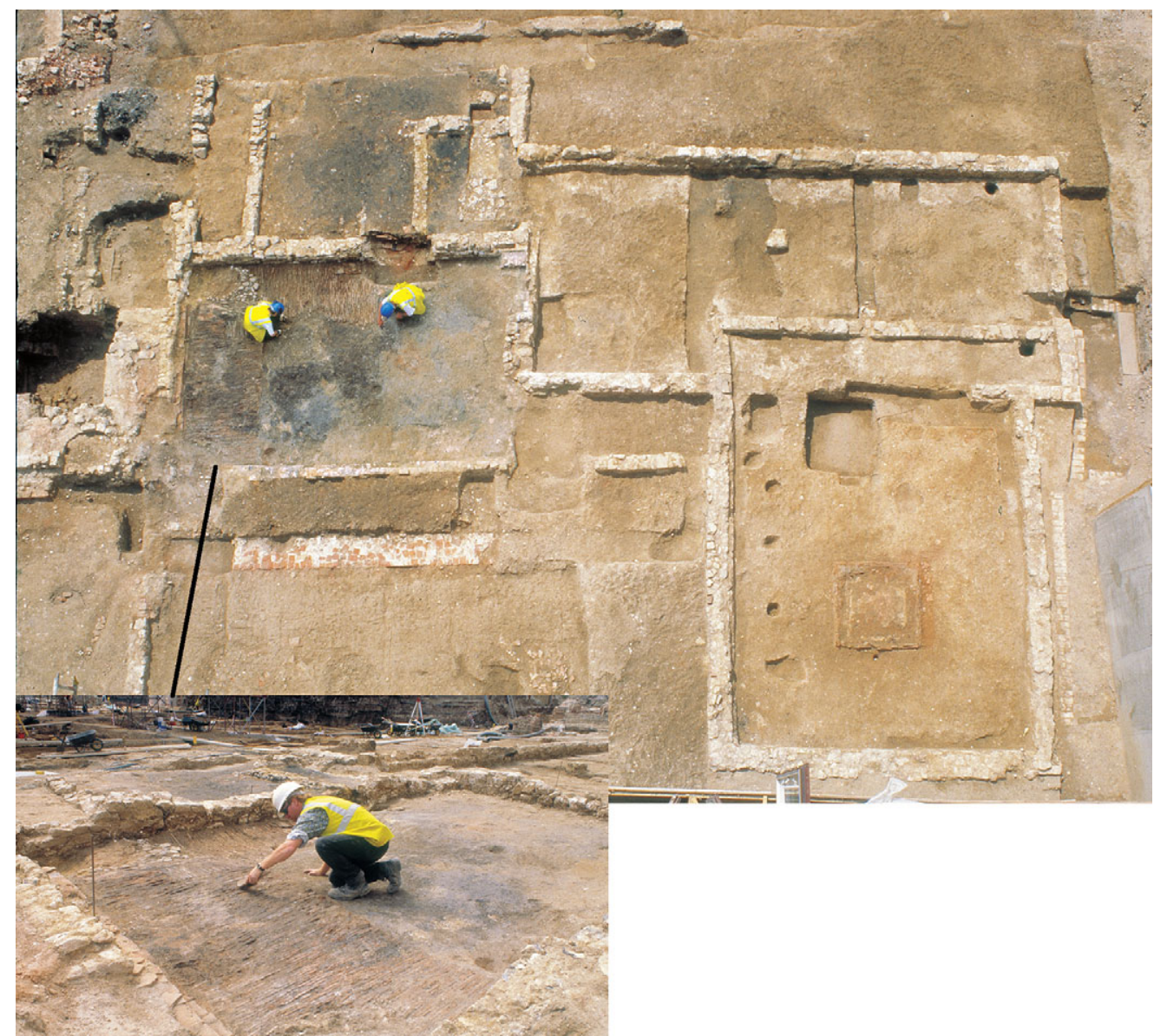

3. I 7 Excavation of distillery at St Mary Spital, London: Canons' infirmary showing the distillery hearths (top left). (C) Museum of London Archaeology

confirmed the presence of numerous mineral elements including lead, copper, iron, silver and phosphorus, but no organic matter was detected (Moorhouse I972: Table I). At Battle Abbey, distillation vessels were founded in association with a small jar containing a mercury residue (Booth 20I7: 207).

Were monastic chemists producing pharmaceuticals for human consumption? The process of distillation was employed for numerous purposes, including cosmetics that contained compounds of lead for whitening the skin (Adams and Forbes 20I5: 38). The same equipment could also have been used to make nitric acid, used in metal refining to separate gold from silver, and for alchemical and metallurgical experiments (Martinón-Torres and Rehren 2005; Moran 2006). Lead and arsenic were used in medieval artists' pigments as well as in pharmaceuticals - and it can be difficult to distinguish between these two applications even where chemical analysis of residues has been carried out (Pérez-Arantegui et al. 20II). Metals and minerals were routinely combined 
with herbs in medical recipes: mercury was used in a large number of medicines, and lead carbonate was employed in the treatment of conjunctivitis (Connell et al. 20I2: 2I0). Mineral materials such as arsenic, sulphur, gypsum, lead, mercury and iron were commonly used in the classical and medieval pharmacopeia for treating diseases of the skin, eyes and sexual organs (Lev 2002). For example, a recipe for distilled water in the Syon Herbal contained quicklime (calcium oxide) and ammonium chloride; this blue water was applied to the eyes to improve vision (Adams and Forbes 2015: 266). Another miracle water (Aqua Mirabilis) from the Syon Herbal was used to treat skin blemishes, leprosy and to preserve youth. The recipe explains that the ingredients should be mixed in a container of iron, steel, gold or silver, depending on the patient's wealth. It calls for scrapings of silver to be mixed with additional ingredients added on successive days: the urine of a boy on the first day; warm white wine on the second day; fennel juice on the third day; egg whites on the fourth day; breast milk on the fifth day; red wine on the sixth day; and egg whites again on the seventh day, distilling slowly, in combination with a prayer or charm (Adams and Forbes 2015: 267).

Further analysis of residues in distilling equipment is needed to improve our understanding of monastic chemistry. An additional route to identifying the medical ingestion of organic and inorganic materials is through trace residues contained in dental calculus (tartar or calcified dental plaque) (Warinner et al. 20I5). Calculus is a complex bacterial deposit that adheres to the tooth enamel as plaque and mineralises quickly. Archaeologists have recently explored the potential for the study of calculus to reveal new evidence for prehistoric diet, but the micro-debris in dental calculus may also reveal plants and minerals that were ingested as medical preparations (Hardy et al. 20I2). Very few studies have been published to date on dental calculus from medieval sites (e.g. Radini et al. 20I6). However, promising results were obtained from the analysis of dental calculus from an adult male skeleton excavated from the medieval necropolis of Can Reiners (Balearic Islands, Spain) dated to the ninth or tenth century (Fiorin et al. 20I8). The male was aged between $2 \mathrm{I}$ and 30 years at death and his skeleton showed no obvious signs of disease. Microscopic evidence was found for the sporangium annulus of a fern consistent with the species Asplenium trichomanes (maidenhair spleenwort). Historical sources confirm the widespread medical use of this species for treatment of the urinary tract (particularly kidney stones), conditions of the skin and as a decongestant. There are no published studies to date of dental calculus in individuals buried at medieval monastic and hospital cemeteries. However, an unpublished study of calculus from skeletons at the monastery of St Oswald's at Gloucester has provided preliminary evidence for raised mercury levels in three skeletons that showed pathological changes consistent with leprosy or syphilis (Flakney 20I5). 
Archaeobotanical evidence from monastic and hospital sites includes plants with specific therapeutic applications (Figure 3.I8). At Merton Priory, exceptionally large quantities of black mustard (Brassica nigra) seeds were recovered from the infirmary area, recommended in Culpepper's Herbal for treatment of coughs, toothache or throat swellings (Miller and Saxby 2007: I28-9). The infirmary drain produced a large number of seeds of celandine (Chelidonium majus), suggested by Gerard's Herbal for treatment of warts and eye troubles (Miller and Saxby 2007: I28-9). Both Merton and St Mary Spital produced seeds of henbane (Hyoscyamus niger), a powerful sedative, but also a common local species that could have been intrusive in the assemblage. A number of plants present at St Mary Spital may have been grown specifically for medical use, including borage (Borago officinalis), catmint (Nepeta cataria), hyssop (Hyssopus officinale) and opium poppy (Papaver somniferum), which was typically prepared in a syrup administered for pain relief (Davis 20I9). Henbane and celandine have also been found at the Isle of May and in the drain at Paisley Abbey (James and Yeoman 2008). Paisley Abbey yielded a variety of plants with possible medical uses, such as hemlock (Conium maculatum), which can be used as a strong sedative, and caper spurge (Euphorbia lathyris), found also at Reading Abbey, and well known as a purgative (Dickson and Dickson 2000: 198). Opium poppy was also present at Paisley and has been reported from Soutra (Scottish Borders) as an organic residue adhering to a jar (Moffat I988-98, SHARP 3: figure I9).

Seeds of Valerian (Valeriana officinalis) and St John's Wort (Hypericum perforatum) have been reported from Soutra, an Augustinian hospital sited on the King's Highway between Edinburgh and London. In herbal medicine today, these plants are used for the treatment of mild depression, anxiety and sleeping disorders. In the Middle Ages, however, they seem to have been employed to promote healing in wounds and fractures (Moffat 20I4). The Soutra project describes itself as 'archaeo-ethnopharmacological'; it considers archaeological evidence in tandem with historical sources, oral tradition and modern botany. The project has focused on the investigation of drains identified by geophysical survey in the I980s, in search of medical waste such as human blood and exotic drug plants. Small-scale excavations focused on the cellar of an accommodation block, separated from the church by a major drain. The investigations have not been fully published but interim reports claimed pollen evidence for exotic spices such as cloves (Moffat I988-98, SHARP 2: 32); while tests for haemoglobin confirmed the presence of vast quantities of human blood, supposedly contaminated with lead from the piped water supply (Yeoman I995: 3I-3). These results have not been replicated in tests undertaken at other hospital sites and the approach has not been taken up more widely. The identification of the presence of human blood at Soutra is of limited value, particularly in the absence of stratigraphic or dating evidence, as we know that phlebotomy was practised routinely at medieval infirmaries. 


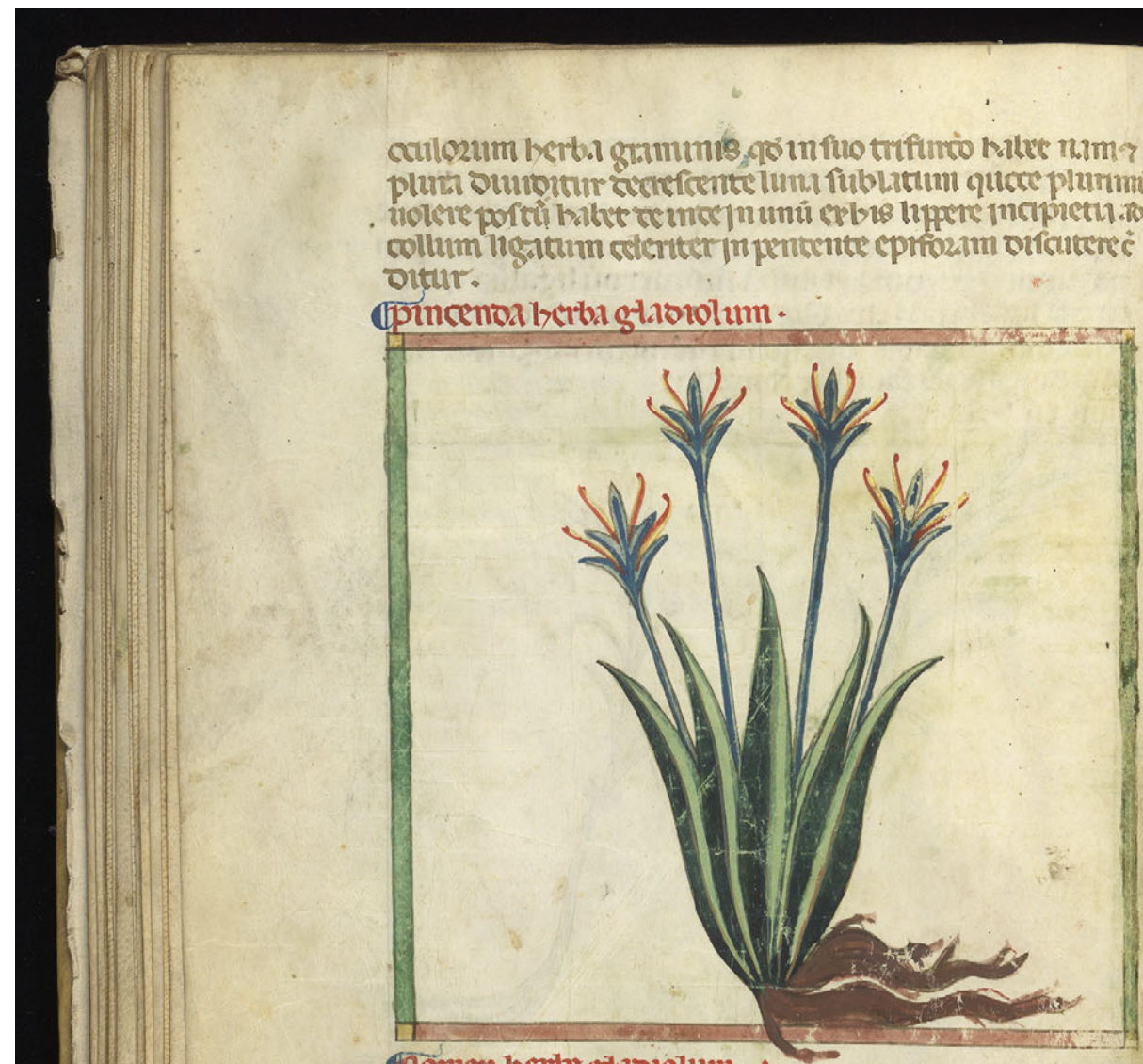

fromen berte gitorolum. .:-2

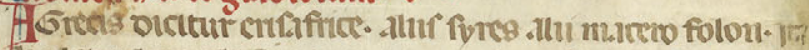

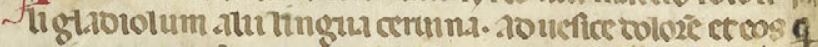

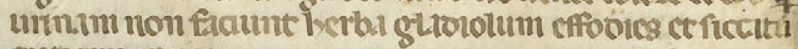

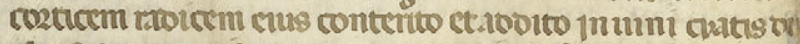
obus aque coatis quztuor contungts et fic potul nabls. 10

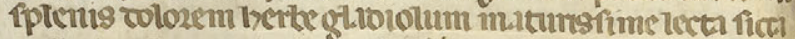

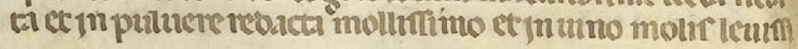


Medieval healing also drew on magic and the use of amulets. The boundary between spiritual and magical practice was permeable even in monastic institutions, a theme that will be taken up in the next chapter. It is noteworthy that relatively few artefacts excavated from monasteries and hospitals can be identified as potential healing amulets, objects that were believed to possess special properties to protect or heal. Examples include objects made of occult materials such as jet or amber, or metal objects which carry sacred inscriptions. One candidate is a Roman intaglio recovered from the drain at Paisley Abbey (Malden 2000: 177). Antique cut gems were made into rings that were particularly favoured by medieval ecclesiastics and are sometimes found in the graves of bishops (Gilchrist 2008). The thirteenth-century Book of Stones by the Dominican Albertus Magnus described the special properties of images in stones, including antique cameos and intaglios, alongside agates and fossils. Albertus regarded the images or 'pictures' in cut gems as having been naturally created, with celestial powers channelled through astrological images (Wyckoff I967: 127-35).

Amulets in more common use were found at St Mary Spital: a woman was buried in an ash-lined coffin with a silver ring dating to the fourteenth century. This has a two-line inscription around the outside of the ring, IASPAR MELCHIOR BALTACZAR IESUS NAZARENUS (Gilchrist and Sloane 2005: 99). This powerful charm combines the names of the three Magi, known for protection against epilepsy, with the formula Jesus Nazarenus, regarded as protection against sudden death (Gilchrist 20I2: I63). Death without preparation was greatly feared by medieval people, since the last rites of confession, communion and the sacrament of extreme unction were required to send the soul on its journey. Seven gold 'angels' were also excavated from St Mary Spital, eight-shilling pieces which carry an image of the archangel St Michael defeating a devil or dragon; on the reverse is a ship with the mast depicted as the Rood. These coins were distributed ceremonially by the king to sufferers of the skin disease scrofula, known as 'the King's Evil'. The gold angels from St Mary Spital were found in a pit in a house within the hospital precinct (Harward et al. 20I9: 279-80). 'Angels' were also used more widely to protect against illness and harm, as confirmed by their occurrence on the Tudor warship, the Mary Rose. Nineteen angels were recovered from the ship, seven of which were worn on mariners' bodies when the ship sank (Besly 2005).

\section{CONCLUSIONS: MONASTIC HEALING TECHNOLOGIES}

A practice-based approach to medieval healing reveals new insight to sensory experience in the medieval infirmary. In summary, the main classes of archaeological evidence for medieval healing are:

- preventative measures including diet, hygiene and care of the body;

- excavated infirmary complexes; 
- potential medical objects from infirmary and cemetery contexts (including glass and ceramic vessels, medical tools, prosthetics and healing amulets);

- archaeobotanical evidence for herbal medicine;

- skeletal evidence for direct medical intervention such as bone-setting, amputation and trephination;

- skeletal evidence for disease and disability from which the extended social care of individuals can be inferred (Roberts 20I7; Tilley 20I7).

Each of these classes of evidence must be critically assessed according to their social and archaeological contexts. What do they tell us about differences in therapeutic treatment between hospitals, monastic infirmaries and (secular) domestic environments? Do they offer any commentary on the experience of patients, or who was responsible for treating them? Can we detect regional traditions or gendered differences in monastic healing technologies?

An interdisciplinary approach enables reconstruction of the sensory and material dimensions of the medieval infirmary. Attention to space confirms evidence for sexual segregation in hospital infirmaries and an increased emphasis on privacy in the later Middle Ages, including partitioned chambers and the possible provision of lockers to securely store personal belongings. Archaeology reveals patterns for the positioning of beds and the movement of nursing staff, engrained as wear patterns in floors at St Mary Merton and St Mary Spital, and highlights the importance of heating, lighting and sanitation in the infirmary (Miller and Saxby 2007; Harward et al. 20I9; Thomas et al. I997). At the hospital of St Mary Spital, the superior accommodation provided for the canons suggests that greater social value was placed on their spiritual ministry for the sick, above the practical vocation of the lay-sisters. Documentary evidence confirms that it was the sisters who performed the most basic care for the body: preparing meals for the sick, keeping the lamps lit, bathing patients and laundering bed sheets. Specialist vessels for feeding the infirm have been identified at the hospitals of St Mary Spital and St Nicholas in St Andrews, and ladles for heating individual portions were found at the monastic infirmary of Merton Priory. This suggests that individual meals were warmed and fed to patients as required, in contrast with the monastic model of communal dining at set times of the day.

As noted above, the prevailing view of medical historians is that medieval hospitals provided 'warmth, rest, basic nursing care and nourishing food' (Rawcliffe 20II: 74). Treatment within the monastic infirmary was more closely informed by academic medicine, revolving around a routine of uroscopy, astrology and blood-letting, to achieve a balance of humours in each individual monk or nun. Peregrine Horden stresses the emphasis placed on rhetoric in medieval medicine over practice or intervention; he suggests that prevention and 'talking cures' were valued over technological intervention, in 
contrast with the prevailing approaches of modern biomedicine (Horden 2007: I38-9). And yet, when the archaeological data are drawn together, there is considerable evidence for medieval healing, some of which was based around active intervention. Technologies of healing evidenced by archaeology include preventative care for the body, medical interventions such as surgery and bone-setting, the provision of prosthetics and specialist medicines (evidenced by archaeobotany and material culture), and extended social care for individuals with long-term disease and disability, evidenced by skeletons excavated from the cemeteries of hospitals and monasteries. The Syon Herbal gives insight to the range of expensive ingredients that enhanced sensory experience in therapeutic treatment, including richly fragranced exotics such as nutmeg, cinnamon, cloves and cumin (Adams and Forbes 2015: 40). It indicates that a strong emphasis was placed by monasteries on remedies to heal eye complaints, matched by archaeological evidence for spectacles found at Syon and elsewhere, reflecting the importance of sight in performing monastic liturgy and literacy.

A significant difference between hospitals and monastic infirmaries is that the latter were masculine environments, with care for the sick undertaken by the monk-infirmarer and male servants. The well-documented case of Norwich Cathedral Priory confirms that the only female servant was the laundressshe provided a supply of clean sheets but is unlikely to have interacted with monastic patients (Rawcliffe 2002). In contrast, nursing in hospital infirmaries was undertaken by lay-sisters who had taken monastic vows, gradually replaced in the later Middle Ages by female nursing servants (Rawcliffe I998). Both environments produce significant archaeobotanical evidence for the use of herbal medicine in treating the sick. Rawcliffe suggests that medieval women were skilful herbalists and that the sisters' gardens at hospitals such as St Giles in Norwich were used to grow medicinal herbs (Rawcliffe I998: 59). The cultivation and processing of herbs, in addition to the skilled preparation of herbal remedies, represent specialist technologies of healing. Nursing sisters drew on the empirical tradition of herbal medicine to treat hospital patients and they may also have been skilled bone-setters. Is it possible that the sisters' empirical knowledge included the distillation of herbal medicines? In the context of noble households in England and Germany, it has been argued that women were responsible for the distillation of medical recipes. This is based on women's ownership of recipe collections and distilling equipment (Rankin 2OI3) and the emphasis placed on women's health within manuscripts featuring recipes for medical distillation, such as the Berkeley Castle Manuscript and the Syon Herbal (Voigts and Payne 2016; Adams and Forbes 2015). Archaeological evidence suggests that medical distillation was carried out principally at monasteries for men; however, distilling equipment has been recorded at the Gilbertine double houses of Watton (East Yorkshire) and Haverholme 
(Lincolnshire) (Moorhouse I972: II3) and the Syon Herbal confirms the importance of pharmaceuticals to a Bridgettine double house. Excavated nunneries have also produced evidence for distillation, including a ceramic distilling base from Polsloe Priory, Exeter (Allan I984: 67), a pottery receptory from Denny Abbey (Cambridgeshire) (Booth 2017: 202), and potential ceramic distillation vessels from a timber building at St Mary Clerkenwell (Sloane 2OI2: 45).

Urinals are commonly recovered from monastic sites, confirming the widespread importance of uroscopy in the monastic regimen, including nunneries such as St Mary Clerkenwell (Sloane 2012: 245). The rarity of vessel glass in Scotland must have limited the practice of both uroscopy and medical distilling. Only two fragments of glass urinal were recovered from the extensive excavations at the hospital of St Mary Spital, perhaps confirming that more academic approaches to medical diagnosis were employed only exceptionally in hospitals. Rare examples of therapeutic and prosthetic devices, ranging from spectacles to hernia trusses, seem to be more closely associated with monastic rather than hospital care. Healing plates were found associated with a burial at the leprosarium at Reading, but this hospital was located within the precinct of Reading Abbey. Clearly there was an overlap in nursing practice between the two types of institution, despite the gender difference in nursing personnel. However, monastic infirmaries seem to have been more likely to import exotic drugs for the dispensary, on the basis of drug jars identified from archaeological contexts to date, including an example from the nunnery of St Mary Clerkenwell.

The strongest indication of healing technology is in the likely production of pharmaceuticals, demonstrated by extensive evidence for glass and ceramic equipment for distillation. The practice was widespread at monasteries and has been detected at hospitals, with residue analysis at St Mary Spital confirming the use of heavy metals in distillations, including mercury, lead, iron, arsenic and copper. It is possible that distilling was carried out in connection with industrial processes such as assaying or in relation to alchemy, as the transmutation of metals was believed to hold the key to youth, health and eternal life (Principe 2013). Medieval monastic chemistry may not have clearly distinguished between practices aimed at pharmacy, alchemy and metallurgy (Booth 20I7). However, the spatial and chronological contexts perhaps suggest a medical function: the large assemblages of distilling equipment recovered from Pontefract and Selborne Priories were concentrated near the monastic latrine blocks, in close proximity to the monks' dormitories (Moorhouse I972: 90, 99). It is unlikely that metalworking processes would have been located so near the sacred space of the church and cloister, and in direct contact with the main water supply that was piped through the monastery. Monastic infirmaries were usually sited in precisely this area, to benefit from the purest water before it 
flushed the latrines of the dormitory and the drains of the kitchen. The medical application of these chemical compounds is confirmed by historical and skeletal evidence that metals such as mercury were used to treat leprosy and treponemal diseases such as syphilis (discussed above). Can we conclude that the hospital patients at St Mary Spital received chemotherapy, using chemical preparations produced at pharmacies within the precinct? The location of the distilling workshops is central to this question: two were adjacent to the canons' dormitory and infirmary, rather than sited with the infirmary of the sick poor. If these workshops were pharmaceutical, their spatial location suggests that the medicines may have been intended for treatment of the canons rather than the sick poor. The third distilling workshop at St Mary Spital was located in a more industrial area of the precinct and may have been operated by secular tenants; the association of a silver litharge cake suggests that this site is more likely to have been connected to assaying and metalworking.

To what extent were these medieval healing technologies exclusive to religious contexts? Herbals and medical manuscripts were also owned by aristocratic families and material culture confirms that uroscopy and distillation sometimes took place in castles and urban settlements, although they are found principally on monastic sites. Fragments of urinals have been excavated from London, Winchester, Southampton and Northampton, and at castles including Conisborough (South Yorkshire) (Thorn I980). Herb gardens were also a prominent feature of castles and distilling equipment has been found in castle excavations, including an exceptional assemblage from Sandal (West Yorkshire) (Moorhouse I983), and fragments from Bodiam (Sussex), Bramber (Sussex) (Moorhouse I977), Wisbech (Cambridgeshire) and Weoley (Warwickshire) (Moorhouse 1972). The Weoley Castle evidence suggests the practice of chemical sublimation for alchemical purposes, comprising an aludel (the top vessel in sublimation apparatus) and a distilling base which retained a mercury residue. To date only one monastic site in Britain has produced an aludel, Byland Abbey (North Yorkshire), suggesting the practice of alchemy (Booth 20I7: 204). Drug jars (albaralli) have also been recorded from castles, including Barnard Castle (co Durham) (Austin 2007: 407), while grooming tools are recovered from urban and castle excavations (Gilchrist 2012: 76-8). These technologies of the medieval body were not exclusive to monastic contexts, but in the medieval countryside, religious institutions were distinctive in their emphasis on clean water supply and scrupulous refuse disposal. In an urban context, English town corporations developed innovative public health strategies in the later Middle Ages, with an emphasis on water supply (Rawcliffe 20I3). Both urban and rural monasteries engaged in a disciplined regimen of the body that included celibacy, hygiene, fasting and daily timetables that governed prayer, study, eating, talking and sleeping. 
Finally, it is worth noting some possible regional and chronological traditions in monastic healing and technologies of the body. Preliminary observations suggest that the degree of medical intervention that took place in monastic and hospital infirmaries varied in different parts of Europe. Archaeological excavation of Icelandic and Swedish monasteries has yielded far more material culture for surgery and medical treatment (Bergqvist 20I4; Kristjánsdóttir 20I0). Johanna Bergqvist attributes the prevalence of these objects in Sweden to the wider 'medical culture' that existed in Scandinavian secular society, proposing that a strong vernacular tradition was already in place around the 'empirical art of healing' before the introduction of monasticism (Bergqvist 20I3). What was the relationship of medieval monastic healing in Britain to earlier, indigenous traditions of care? Reformed monasticism introduced new ideas about care for the body and influenced the foundation of medieval hospitals dedicated to Christian charity. Recent archaeological investigations at the sites of English medieval hospitals have detected signs of earlier specialist cemeteries, dating to the late Saxon period. Archaeological evidence from Winchester, St Mary Spital and Partney suggests that we should be alert to the possibility that charitable institutions may have been in operation by the tenth or eleventh century, before Norman colonisation. We should also consider whether the locations of hospitals founded in the twelfth century or later may have been selected to harness the healing qualities of earlier therapeutic landscapes. In Scotland, the boom in hospital foundations appears to have been as late as the fifteenth century, on the basis of historical evidence. How many holy wells, shrines, hospitals and monasteries were re-founded at places renowned for an earlier healing tradition, such as the largely undocumented case of the Isle of May? A priority for future research is the investigation of regional differences in monastic healing and their relationship to earlier therapeutic landscapes. 